\title{
Study of Aggregate Dividends, Aggregate Earnings among Indian Companies: A Case of Emerging Market
}

\author{
Nishant B. Labhane (Corresponding author) \\ Senior Research Fellow, Department of Humanities and Social Sciences, Indian \\ Institute of Technology Kharagpur, Kharagpur - 721302, West Bengal, India \\ Tel: 91-738-448-0866_ E-mail: nishant.labhane@hotmail.com
}

\begin{abstract}
Jitendra Mahakud
Associate Professor (Economics and Finance Area), Department of Humanities and Social Sciences, Indian Institute of Technology Kharagpur, Kharagpur - 721302, West Bengal, India

E-mail: jmahakud@hss.iitkgp.ernet.in; jmahakud@yahoo.com
\end{abstract}

Received: November 24, 2015 Accepted: November 29, 2015 Published: May 19, 2016

doi:10.5296/bms.v7i1.9486 URL: http://dx.doi.org/10.5296/bms.v7i1.9486

\begin{abstract}
This study examines the behavior of aggregate dividends and earnings for 781 sample firms listed on the National Stock Exchange (NSE) in Indian capital market for a period from 1995 to 2013. Although the number of dividend paying firms decreased, the aggregate dividends have increased manifold over the last two decades. Further, we notice a significant variation in the level of aggregate dividends and earnings between the standalone and business group affiliated firms. This implies the relevance of corporate relationship of firms in explaining their dividend behavior. We find evidence for dividend and earnings concentration for entire sample firms and within a sample of Indian firms identifiable with organizational forms reflecting these corporate relationships, with fewer firms paying most dividends. The dividend paying firms exhibit two groups between which one group, with small number of firms having high earnings contributes major proportion of total earnings collectively and influences the aggregate dividend supply. Our analysis exhibits strong correlation between a firm's earnings and its dividend payout, where, the firms with high level of earnings are more
\end{abstract}




\section{Macrothink}

Business Management and Strategy ISSN 2157-6068 2016, Vol. 7, No. 1

likely to pay dividends while the firms suffering from losses are most likely to cut or omit the dividends. Finally, we do not find any evidence in support of reduced propensity to pay dividends in Indian capital market unlike the declining propensity to pay in global trends.

JEL classification: G35; G30

Keywords: Dividends, Aggregate dividends, Payout policy, Earnings concentration, Propensity to pay 


\section{Introduction}

Dividend is that portion of firm's earnings which is given back to its shareholders. The dividend decisions, as determined by dividend policy, are a type of financing decisions that affects both the shareholder wealth and firms retain earnings. Dividend policy is defined as that payout policy which determines the amount of cash distributed to shareholders over time. The dividend policy is a key area of research in finance for academicians, financial analysts, managers and researchers for about six decades now (Singhania, 2005). However, there is no consensus about why firms pay dividend and why investors value dividend resulting into a “dividend puzzle," as coined by Black (1976).

Under the assumption of perfect capital market with no taxes, zero transaction and agency costs; full availability of information, Miller and Modigliani (1961) put forward dividend irrelevance theory, which says that the firm's investment policy is the sole determinant of firm value and if managers make reasonable investment choices, the dividend policy should take care of itself. But in a real world, capital market is not perfect and dividend policy affects firm value and shareholders wealth. Over the years the researchers have relaxed the assumptions of Miller and Modigliani one by one, which led them to propose different dividend policy theories such as tax clientele, signaling, agency cost and firm life cycle theory (Jensen and Meckling, 1976; Litzenberger and Ramaswamy, 1979; Bhattacharya, 1979; Aharony and Swary, 1980; Rozeff, 1982, Easterbrook, 1984 and DeAngelo and DeAngelo, 2006) to explain why firms pay dividends.

While most of the previous studies focused on the determinants of dividend policy, few studies showed a trend between dividend payouts vis-a-vis characteristics of dividend paying firms. Fama and French (2001) document that the percentage of nonfinancial and nonutility firms paying cash dividends has declined from 66.5 per cent in 1978 to 20.8 per cent in 1999. In spite of the fall in number of dividend paying firms and decline in propensity to pay dividend among U.S. industrial firms, the aggregate amount of dividends increased over last two decades (DeAngelo, et al., 2004). Ferris, et al. (2006) examined the existence of this phenomenon in Japanese and U.K. capital markets and find modest increase in aggregate dividends in U.K. and Japan. They also find evidence for concentration in the supply of dividends with few numbers of firms contributing considerable proportion of dividend supply in U.K., but not in Japan. A relatively small number of firms paying the overwhelming majority of aggregate dividends are known as the concentration of dividend.

Although, the above mentioned phenomenon of increase in aggregate dividends, dividends and earnings concentration is examined in developed capital markets, a few studies (Lukose and Komera, 2013) noted it in the emerging capital markets. The emerging financial markets (EFMs) differ from developed financial markets (DFMs) in many ways: first, there is legal constraints on the amount to be distributed to shareholders in EFMs; second, the EFMs have undergone privatization and liberalization of capital accounts in last two decades whereas, DFMs were liberalized long back (Beim and Calomiris, 2001); third, EFMs are exposed to more macroeconomic volatility than DFMs (Beim and Calomiris, 2001). Thus, it is important 
to examine the above phenomenon in EFMs too.

Why did the aggregate real dividends increased despite a decline in the number of payers? Is the increase in dividend concentration a result of corresponding increase in earnings concentration? What is the pattern in aggregate dividend supply? What is the relationship between dividend payment decision and earnings and losses? Has the propensity to pay dividend reduced? The term "reduced propensity to pay" appear to entail that the dividend payers now pay lower proportion of their profits than earlier. These questions prompt us to carry out the current study.

The present study examines the aggregate dividends and earnings behavior a sample of 781 firms listed in National Stock Exchange (NSE) in India as a representative case of emerging market for the period 1994-95 to 2012-13. The sample is selected from National Stock Exchange (NSE), which was established on the eve of implementation of new economic policy and the study being focused on the post-liberalization period in India. The NSE's choice was influenced by the fact that the firms enlisted on NSE follows the financial and regulatory norms set by Securities and Exchange Board of India (SEBI). Following Fama and French (2001a) we exclude the financial services and utilities sector firms as the accounting practices and the regulation norms followed by these firms are different.

Further, the presence of various forms of corporate organizational structure in India allows us to examine the behavior of aggregate dividends and earnings of standalone and business group affiliated firms separately. This might deepen our understanding of dividend policies of different corporate forms found in the Indian capital markets. The dividend payout ratios of business group affiliated firms are higher than those of standalone firms, but, there is weaker evidence to support the view that this is related to the level of group size and diversification. Although, business group mitigate imperfections by building internal capital markets, they remain vulnerable to information problems in the dividend payment decision (to pay or not to pay?) and the payout level decision (how much to pay?) (Manos, et al., 2012).

We find dividend and earning concentration among sample Indian firms and corporate organizational structure forms and this concentration increased considerably over the last two decades with fewer firms paying more dividends. There has been emergence of two groups with one group with small numbers of firms and high earnings dominated the aggregate dividend supply. Further, we observe a substantial variation in the level of aggregate dividends and earnings behavior between the standalone and business group affiliated firms in Indian capital market.

The remainder of the research paper is organized as follows. Section 2 reviews the empirical literature on the recent trends in dividends, dividend payers, the phenomenon of disappearing dividends, the behavior of aggregate dividends and earnings and their concentration; Section 3 describes sampling procedure and methodology; Section 4 analyses the aggregate dividends and earnings behavior and the relationship between the two; Section 5 concludes the research paper. 


\section{Review of Literature}

This section reviews the recent trends in dividends, dividend payers, the phenomenon of disappearing dividends, the behavior of aggregate dividends, aggregate earnings and the concentration of dividends and earnings.

In their intriguing study, Fama and French (2001) find that the number of non-financial, non-utility dividend paying firms declines from 66.5 per cent in 1978 to 20.8 per cent in 1999 . They find two basic reasons for decline, first the characteristics of newly listed firms on exchange tilted towards firms with lower profitability and stronger growth opportunities, which are the characteristics of firms that never paid dividends. Fama and French, further find that even after controlling for such characteristics, firms are less likely to pay dividends and this phenomenon is referred to as the declining propensity to pay. In spite of disappearing dividends among U.S. industrial firms, DeAngelo et al. (2004) document a considerable increase in aggregate level of dividends. They find evidence for concentration in dividend supply with fewer firms paying more dividends than earlier and increase in consolidation in earnings among U.S. industrial firms.

Several researchers have examined the presence of concentration of dividends in other capital markets apart from U.S. Ferris et al. (2006) find an increase in aggregate dividends in both Japan and the U.K., but they find no evidence of increasing dividends concentration among Japanese firms, however, the payment of dividends appear highly concentrated among U.K. firms. Denis and Osobov (2008) examine the dividend payment behavior in six different countries like U.S., U.K., Canada, Germany, France and Japan over the period from 1989 to 2002. They find evidence for rise in aggregate real dividends between 1990 and 2002 for all the countries except Canada and also find the concentration of dividend payment among the largest and most profitable firms in all six countries.

Examining the dividend payment behavior of firms in European Union (EU), Eije and Meggison (2008) observes an increase in concentration of dividends and earnings with the EU and further report that the largest decile of the dividend payers paid the 81 per cent of total dividends.Utilizing data from a large sample of more than 17,000 firms from 33 different countries over the period 1985-2006 period, Fatemi and Bildik (2012) find evidence in support of decline in propensity to pay dividends worldwide. Moreover, the aggregate dividends are highly concentrated among a small numbers of dividend payers and mean dividend payout ratio declined more in civil law countries as compared to common law countries.

Although, above discussed researchers investigated this issue in developed capital markets, few studies addressed this issue in developing capital markets. Studies such as Reddy and Rath (2006) examined the issue of disappearing dividends in emerging markets such as India and find decline in proportion of dividend paying firms from 57 per cent in 1991 to 32 per cent in 2001. However, they haven't addressed the issue of increase in aggregate real dividends and concentration of dividend payments in emerging markets. 
La Porta et al. (2000), use a large dataset to examine the impact of legal regime on dividend policy in 33 different civil law and common law countries. They contend that common law countries provide greater degree of protection to minority shareholders than civil law countries. And the minority shareholders in common law countries are able to extract more dividends from controlling shareholders as compared to civil law countries where such protection is weaker. Thus, this study addresses the issue of influence of legal regime on the behavior of aggregate dividend over the period of study in common law country like India.

Finally, the presence of corporate organizational structure forms in India such as standalone firms and business group affiliated firms allows us to examine the differences in dividend behavior for these two forms. Studies such as Manos et al. (2012), find that the dividend policy decision of business group affiliated firms is more sensitive to the level of information asymmetry than standalone firms. Thus, the study of dividend policy of standalone and business group affiliated firms separately allows us to investigate how the corporate organizational structure forms affects the need for dividends in order to reduce informational asymmetry problem.

\section{Sampling Procedure and Methodology}

The data is collected from CMIE's (Centre for Monitoring Indian Economy) Prowess database which is a largest database of financial performance of Indian firms. The sample firms are selected from firms listed on National Stock Exchange (NSE) for the empirical study. National Stock Exchange (NSE) is country's leading stock exchange and firms enlisted on NSE follows the financial norms set by Securities and Exchange Board of India (SEBI). The reason to choose sample firms from NSE is that it was established on the eve of implementation of new economic policy in India.

Amongst the measures of central tendency, the three most important ones: the arithmetic average or mean, median and mode are used to analyze the behavior of aggregate dividends and earnings. The measures of dispersion such as variance and standard deviation are utilized to find the variations in the dividend payouts. The average of annual median and the year-wise cross sectional analysis is carried out to examine the relationship between the aggregate dividends and earnings in the study.

The period of study is from 1994-95 to 2012-13 which covers the post liberalization period and maximum financial information is available for sample firms in database during this period. Also, during this period the shareholding pattern of sample firms changed and the availability of alternative sources of finance increased for the sample firms which creates our interest to examine the above period of study. The data is collected on annual basis where the financial year runs from $1^{\text {st }}$ April to $31^{\text {st }}$ March Hereafter, the financial year 1994-95 will be referred to as 1995 and accordingly, the financial year 2012-13 as 2013. Presently, a total of 1730 firms are listed on NSE out of which 179 are financial services, 28 are from utilities sector and 35 are public sector enterprises. The financial services and utilities sector firms are excluded as the accounting practices and the regulation norms followed by these firms are 
different. The public sector enterprises are excluded from sample as their dividend payment decisions are influenced by government.

The remaining firms are 1488 out of which the maximum financial information is available for 781 firms. So, the final sample of study consists of 781 firms. The 781 sample firms consists of 493 business group affiliated firms and 288 standalone firms. A business group is an organizational structure consisting of legally independent firms that are bound to each other by formal or informal ties and are expected to take coordinated actions (Khanna and Rivkin, 2001). Whereas, a standalone firm is an independent operating firm that is not subsidiary to another firm. We examine the dividend policy of business group affiliated and standalone firms separately in our study due to their different way of operation.

\section{Concentration in Dividends Payment and Earnings and the Payout Ratios}

\subsection{Trends in Aggregate Dividends, Aggregate Earnings and Dividend Payout Ratio}

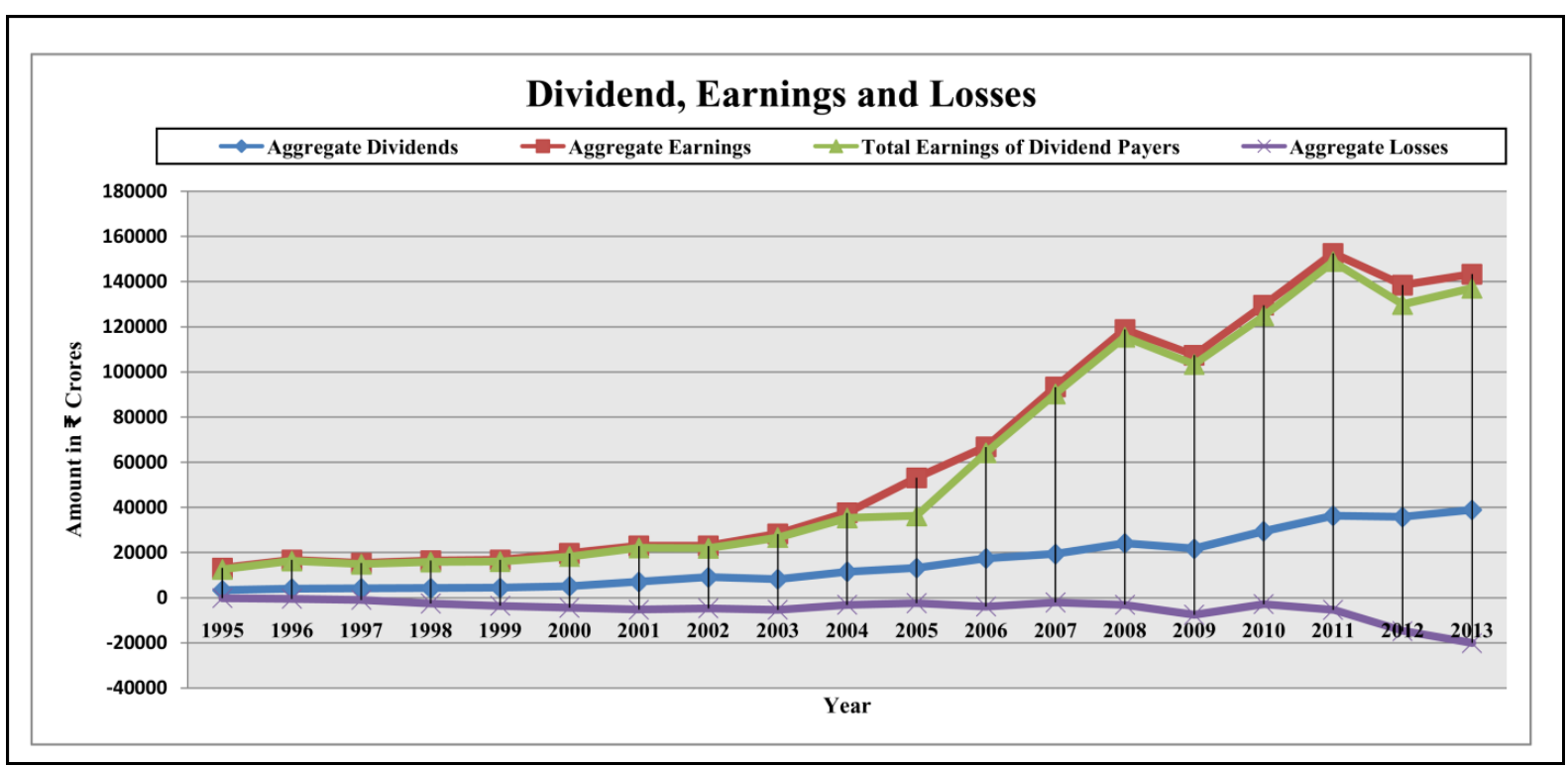

Figure 1. Dividends, earnings and losses for 781 sample firms from 1995 to 2013. Aggregate dividends are sum of dividends paid by all the firms for that year, aggregate earnings are sum of earnings of dividends payers and non-payers for that year, total earnings of dividend payers are sum of earnings for all firms that paid dividends during that year, aggregate losses are sum of losses for all loss making firms for that year.

We analyze the behavior of dividends and earnings by first examining the level of aggregate dividends, earnings and losses. Especially, we investigate to examine how the aggregate value of dividends, earnings and losses changes over the period of study. Figure 1 depicts the aggregate dividends, aggregate earnings, total earnings of dividend paying firms and aggregate losses for 781 sample Indian firms listed on NSE for the period from 1995 to 2013. From the figure it appears that (i) the aggregate dividends increased steadily over the period of study 1995 to 2013 only except during 2003, 2009 and 2012 when the aggregate dividends showed a downward trend. (ii) the aggregate dividends moved in line with the aggregate 
earnings for almost all the year of the study. (iii) the earnings of dividend paying firms account for a vast proportion of aggregate earnings for all the year of study. (iv) the aggregate losses too increased steadily during the period of study reaching to its highest in the year 2013.

The results regarding aggregate dividends and earnings are consistent with the findings of DeAngelo, et al. (2004) reported for U.S. capital market during 1950-2000 where the aggregate dividends showed linear upward trend and grew with the growth in aggregate earnings. Whereas, these results are inconsistent with the Japanese and U.K. capital markets where the aggregate dividends gone up and went down with the respective country's economy for the period 1990-2001. Tables 1 and 2 focus in more detail regarding this issue for sample Indian firms and various forms of corporate organizational structure during 1995 to 2013. The nominal value of dividends and earnings is converted into real term by using the GDP deflator with 1995 year as a base with index 100. The GDP deflator is an alternate measure of inflation and it is obtained by dividing current price GDP with constant price GDP.

Table 1 presents the aggregate nominal and real dividends and aggregate dividend payout ratio for Indian and various forms of corporate organizational structure for 1995-2013. The aggregate dividend payout ratio is measured as aggregate dividend paid divided by aggregate earnings during that period. The aggregate dividend payout ratio fluctuated for the entire period of study for Indian firms from as high as 39.49 per cent in 2002 to as low as 20.25 per cent in 2009 with a mean and median payout ratio of 26.12 per cent and 25.85 per cent respectively. The total amount of dividends distributed by the business group affiliated firms in terms of total earnings exhibits variability with standard deviation of 5.35 per cent in aggregate dividend payout ratio as compared to standalone firms with 4.52 per cent.

Table 1. Aggregate nominal and real dividends for Indian firms and corporate organizational structure forms

\begin{tabular}{|c|c|c|c|c|c|c|c|c|c|}
\hline \multirow{3}{*}{ Year } & \multirow{2}{*}{\multicolumn{3}{|c|}{$\begin{array}{l}\begin{array}{l}\text { Aggregate dividends for Indian } \\
\text { firms }\end{array} \\
\text { Indian Firms }\end{array}$}} & \multicolumn{6}{|c|}{$\begin{array}{l}\text { Aggregate dividends for Standalone and Business Group Affiliated Indian } \\
\text { firms }\end{array}$} \\
\hline & & & & \multicolumn{3}{|c|}{ Standalone Firms } & \multicolumn{3}{|c|}{ Business Group Affiliated Firms } \\
\hline & $\begin{array}{l}\text { Nominal } \\
\text { Dividend } \\
\text { (₹ } \\
\text { million) }\end{array}$ & $\begin{array}{l}\text { Real } \\
\text { Dividends } \\
\text { (₹ } \\
\text { million) }\end{array}$ & $\begin{array}{l}\text { Aggregate } \\
\text { dividend } \\
\text { payout } \\
\text { ratio }(\%)\end{array}$ & $\begin{array}{l}\text { Nominal } \\
\text { Dividends } \\
\text { (₹ } \\
\text { million) }\end{array}$ & $\begin{array}{l}\text { Real } \\
\text { Dividends } \\
\text { (₹ } \\
\text { million) }\end{array}$ & $\begin{array}{l}\text { Aggregate } \\
\text { dividend } \\
\text { payout } \\
\text { ratio }(\%)\end{array}$ & $\begin{array}{l}\text { Nominal } \\
\text { Dividends } \\
\text { (₹ } \\
\text { million) }\end{array}$ & $\begin{array}{l}\text { Real } \\
\text { Dividends } \\
\text { (₹ } \\
\text { million) }\end{array}$ & $\begin{array}{l}\text { Aggregate } \\
\text { dividend } \\
\text { payout } \\
\text { ratio }(\%)\end{array}$ \\
\hline 1995 & 33544.5 & 33544.5 & 25.45 & 5540.8 & 5540.8 & 26.85 & 28003.7 & 28003.7 & 25.19 \\
\hline 1996 & 40549.5 & 38729 & 24.11 & 5715.6 & 5443.4 & 23.86 & 34833.9 & 33270 & 24.15 \\
\hline
\end{tabular}




\begin{tabular}{|c|c|c|c|c|c|c|c|c|c|}
\hline 1997 & 41689.6 & 36318.8 & 27.1 & 5961.7 & 5184.1 & 24.62 & 35727.9 & 31125.1 & 27.57 \\
\hline 1998 & 42395.4 & 34177.9 & 25.73 & 6667 & 5376.6 & 21.99 & 35728.4 & 28803.2 & 26.57 \\
\hline 1999 & 43978.2 & 33973.4 & 26.19 & 7421.4 & 5753 & 23.21 & 36556.8 & 28240.3 & 26.89 \\
\hline 2000 & 51119.2 & 38089.9 & 26 & 11052.5 & 8248.1 & 29.04 & 40066.7 & 29854.5 & 25.28 \\
\hline 2001 & 70259 & 50578.6 & 30.6 & 11810.3 & 8496.6 & 28.56 & 58448.7 & 42076.5 & 31.05 \\
\hline 2002 & 90778.6 & 63385.2 & 39.49 & 13024.9 & 9108.3 & 28.65 & 77753.7 & 54290.7 & 42.16 \\
\hline 2003 & 82355.8 & 55385.3 & 29.11 & 16724.4 & 11224.4 & 30.73 & 65631.4 & 44137.9 & 28.72 \\
\hline 2004 & 115353.5 & 73634.4 & 30.64 & 26537.9 & 16903.1 & 35.56 & 88815.6 & 56694.3 & 29.42 \\
\hline 2005 & 131926.9 & 80594.5 & 24.8 & 27282.2 & 16635.5 & 25.37 & 104644.7 & 63927.7 & 24.66 \\
\hline 2006 & 174214 & 100527.4 & 26.08 & 42680.7 & 24670.9 & 32.15 & 131533.3 & 75899.2 & 24.57 \\
\hline 2007 & 194090.1 & 105878.3 & 20.79 & 39083.8 & 21357.3 & 22.76 & 155006.3 & 84557.7 & 20.34 \\
\hline 2008 & 241763.4 & 120998.9 & 20.33 & 58789 & 29394.5 & 28.05 & 182974.4 & 91575.9 & 18.68 \\
\hline 2009 & 217559.9 & 104186.9 & 20.25 & 53770.4 & 25727.5 & 24.57 & 163789.5 & 78436.9 & 19.15 \\
\hline 2010 & 294758.3 & 128756.8 & 22.75 & 86823.4 & 37914.1 & 32.98 & 207934.9 & 90830.4 & 20.14 \\
\hline 2011 & 363634.6 & 146222.9 & 23.83 & 109318.5 & 43903 & 37.35 & 254316.1 & 102264.3 & 20.63 \\
\hline 2012 & 358115 & 133601.7 & 25.85 & 108003.8 & 40299.9 & 33.92 & 250111.2 & 93308.8 & 23.44 \\
\hline 2013 & 389529.1 & 135275.2 & 27.18 & 108860.6 & 37798.8 & 30.5 & 280668.5 & 97470.2 & 26.07 \\
\hline Mean & & & 26.12 & & & 28.46 & & & 25.51 \\
\hline Median & & & 25.85 & & & 28.56 & & & 25.19 \\
\hline $\begin{array}{l}\text { Standard } \\
\text { Deviation }\end{array}$ & & & 4.41 & & & 4.52 & & & 5.35 \\
\hline $\begin{array}{c}\text { Raw } \\
\text { change: }\end{array}$ & & & & & & & & & \\
\hline
\end{tabular}


Table 2 shows descriptive statistics regarding the dividend payment behavior by sample Indian firms and various forms of corporate organizational structure such as standalone firms and business group affiliation firms for the period from 1995 to 2013. The aggregate nominal dividends increased by 1061.23 per cent for sample Indian firms, from ₹ . 33544.50 million in 1995 to ₹. 389529.10 million in 2013, while the aggregate real dividends increased by 303.27 per cent to ₹ . 101730.70 million. The mean real dividends (per dividend paying firms) increased from ₹ . 54.10 million in 1995 to ₹ . 268.40 million in 2013 while the median real dividends (per dividend paying firm) increased from ₹ . 14.80 million in 1995 to ₹ . 33.10 million in 2013. The difference between the mean and median dividends and thereby, the increase between the two from 1995 to 2013 suggests that there is concentration of dividends among fewer firms.

Table 2 also suggests that the numbers of dividend paying firms out of 781 sample Indian firms decreased from 620 in 1995 to 504 in 2013 by 18.71 per cent. But, if we examine all the 1732 firms listed on NSE (National Stock Exchange) the number of dividend paying firms increased from 836 in 1995 to 937 in 2013 by 12.08 per cent. The decline in proportion of firms paying dividends is observed more in case of firms listed on Bombay Stock Exchange (BSE), where the firms decline from 1963 in 1995 to 1396 firms in 2013 by 28.88 per cent.

In case of various forms of corporate organizational structure, the aggregate nominal dividends increased by 1864.71 per cent and 902.26 per cent, while the aggregate real dividends increased by 582.19 per cent and 248.06 per cent, for standalone and business group affiliated firms respectively from 1995 to 2013. This suggests that the aggregate amount of dividends in terms of percentage increased by twofold for standalone firms than business group affiliated firms from 1995 to 2013. The number of dividend paying firms decreased from 420 in 1995 to 336 in 2013 by 20 per cent for business group affiliated firms and from 200 in 1995 to 168 in 2013 by 16 per cent for standalone firms. When we consider all the 1732 and 5196 firms listed on NSE and BSE respectively, the numbers of dividend payers on NSE increased by 34.47 per cent and 1.75 per cent for standalone firms and business group affiliated firms respectively. While the numbers of dividend paying firms on BSE declined for both various forms of corporate organizational structure i.e. standalone firms by 34.81 per cent and business group affiliated firms by 21.63 per cent.

Table 2. Descriptive statistics regarding dividend payment by Indian firms and corporate organizational forms from 1995 to 2013

\begin{tabular}{|l|c|c|c|}
\hline \multirow{2}{*}{ Variable } & $\begin{array}{c}\text { Descriptive statistics for dividend } \\
\text { payments by Indian firms }\end{array}$ & \multicolumn{2}{|c|}{$\begin{array}{c}\text { Descriptive statistics for dividend payments by Standalone and Business } \\
\text { Group Affiliated Indian firms }\end{array}$} \\
\cline { 2 - 4 } & Indian Firms & Standalone Firms & Business Group Affiliated Firms \\
\hline
\end{tabular}




\begin{tabular}{|c|c|c|c|c|c|c|c|c|c|}
\hline & 1995 & 2013 & $\begin{array}{c}\text { Absolute } \\
(\%) \\
\text { change }\end{array}$ & 1995 & 2013 & $\begin{array}{c}\text { Absolute } \\
(\%) \\
\text { change }\end{array}$ & 1995 & 2013 & $\begin{array}{c}\text { Absolute } \\
(\%) \\
\text { change }\end{array}$ \\
\hline $\begin{array}{l}\text { 1. Aggregate } \\
\text { nominal dividends } \\
\text { (₹ million) }\end{array}$ & 33544.50 & 389529.10 & 355984.60 & 5540.80 & 108860.60 & 103319.80 & 28003.70 & 280668.50 & 252664.80 \\
\hline & & & 1061.23 & & & 1864.71 & & & 902.26 \\
\hline $\begin{array}{l}\text { 2. Aggregate real } \\
\text { dividends } \\
\text { million, } \\
\text { base) }\end{array}$ & 33544.50 & 135275.20 & 101730.70 & 5540.80 & 37798.80 & 32258.00 & 28003.70 & 97470.20 & 69466.50 \\
\hline & & & 303.27 & & & 582.19 & & & 248.06 \\
\hline $\begin{array}{l}\text { 3. Mean real } \\
\text { Dividends (₹ } \\
\text { million, per } \\
\text { dividend-paying } \\
\text { firm) }\end{array}$ & 54.10 & 268.40 & 214.30 & 27.70 & 225.00 & 197.30 & 66.70 & 290.00 & 223.40 \\
\hline & & & 396.01 & & & 712.13 & & & 335.01 \\
\hline $\begin{array}{l}\text { 4. Median real } \\
\text { dividend }(₹ \\
\text { million, per } \\
\text { dividend-paying } \\
\text { firm) }\end{array}$ & 14.80 & 33.10 & 18.30 & 8.30 & 15.90 & 7.60 & 22.20 & 45.80 & 23.60 \\
\hline & & & 123.47 & & & 92.02 & & & 106.69 \\
\hline $\begin{array}{l}\text { 5. Number of } \\
\text { dividend-paying } \\
\text { companies out of } \\
781 \text { sample } \\
\text { companies }\end{array}$ & 620 & 504 & -116.00 & 200 & 168 & -32.00 & 420 & 336 & -84.00 \\
\hline & & & -18.71 & & & -16.00 & & & -20.00 \\
\hline $\begin{array}{l}\text { 6. Percent of } \\
\text { Companies that } \\
\text { paid dividends out } \\
\text { of } 781 \text { sample } \\
\text { companies }\end{array}$ & 79.39 & 64.53 & -14.85 & 69.44 & 57.64 & -11.81 & 85.19 & 68.15 & -17.04 \\
\hline $\begin{array}{l}\text { 7. Number of } \\
\text { dividend-paying } \\
\text { companies out of } \\
\text { total companies }\end{array}$ & 836 & 937 & 101.00 & 264 & 355 & 91.00 & 572 & 582 & 10.00 \\
\hline
\end{tabular}




\begin{tabular}{|c|c|c|c|c|c|c|c|c|c|}
\hline \multicolumn{10}{|l|}{$\begin{array}{l}\text { listed on NSE i.e. } \\
1732\end{array}$} \\
\hline & & & 12.08 & & & 34.47 & & & 1.75 \\
\hline $\begin{array}{l}\text { 8. Percent of } \\
\text { Companies that } \\
\text { paid dividends out } \\
\text { of total companies } \\
\text { listed on NSE }\end{array}$ & 48.27 & 54.10 & 5.83 & 33.33 & 44.82 & 11.49 & 60.85 & 61.91 & 1.06 \\
\hline \multirow[t]{2}{*}{$\begin{array}{l}\text { 9. Number of } \\
\text { dividend-paying } \\
\text { companies out of } \\
\text { total companies } \\
\text { listed on BSE i.e. } \\
5196\end{array}$} & 1963 & 1396 & -567.00 & 1080 & 704 & -376.00 & 883 & 692 & -191.00 \\
\hline & & & -28.88 & & & -34.81 & & & -21.63 \\
\hline $\begin{array}{l}\text { 10. Percent of } \\
\text { Companies that } \\
\text { paid dividends out } \\
\text { of total companies } \\
\text { listed on BSE }\end{array}$ & 37.78 & 26.87 & -10.91 & 29.98 & 19.54 & -10.44 & 55.40 & 43.41 & -11.98 \\
\hline
\end{tabular}

\subsection{Concentration in Dividends Payment}

4.2.1 Concentration in the Total amount of Dividends Paid and the Increase Therein over the Last Two Decades

Table 3 ranks dividend paying firms from largest to smallest by total amount of cash dividends paid in 1995 and in 2013 in a group of 100 firms. For each ranked group the first two columns indicates the percent of total dividends paid, the middle two columns indicates the cumulative percent, and the last two columns indicates the total amount of real dividends paid with 1995 year as base. In 1995 a total of 620 firms paid dividends (200 standalone and 420 business group affiliated firms) and 504 in 2013 (168 standalone and 336 business group affiliated firms). The top 100 dividend payers in Panel A contributed 73.29 per cent of total dividends paid in 1995 and 89 per cent in 2013. The cumulative percentage of total dividends reports that the top 200 dividend paying firms supplied 86.42 per cent in 1995 and 96.01 per cent of dividends in 2013. The result suggests that relatively small numbers of firms supplied a major proportion of total dividends during that year and this proportion increased considerably over the last two decades. Thus, the concentration of dividends increased over the last two decades with large number of smallest dividend paying firms either reducing the amount of dividends paid or omitting the dividends from 1995 to 2013.

The concentration of dividends is also observed among the various forms of corporate organizational structure in Panel $\mathrm{B}$ and $\mathrm{C}$, where the total amount of dividends paid 
concentrated considerably for the business group affiliated firms as compared to standalone firms among top 100 dividend payers from 1995 to 2013. The results are consistent with that of DeAngelo, et al. (2004) and Ferris, et al. (2006) who finds a high concentration of dividends and the increase therein, with a small number of firms contributing large proportion of total dividends supplied.

Table 3. Concentration of total ₹ dividends paid by Indian firms and corporate organizational structure form in 1995 and in 2013

\begin{tabular}{|c|c|c|c|c|c|c|}
\hline \multicolumn{7}{|c|}{ Panel A: Concentration of total ₹ dividends paid by Indian firms in 1995 to 2013} \\
\hline \multirow[t]{2}{*}{ Dividend ranking } & \multicolumn{2}{|c|}{$\begin{array}{l}\text { Percent of total } \\
\text { dividends }(\%)\end{array}$} & \multicolumn{2}{|c|}{$\begin{array}{c}\text { Cumulative } \% \text { of total } \\
\text { dividends }(\%)\end{array}$} & \multicolumn{2}{|c|}{$\begin{array}{c}\text { Real dividends } \\
\text { (₹ million, } 1995 \text { base) }\end{array}$} \\
\hline & 1995 & 2013 & 1995 & 2013 & 1995 & 2013 \\
\hline Top 100 & 73.29 & 89.00 & 73.29 & 89.00 & 24585.80 & 120380.30 \\
\hline $101-200$ & 13.13 & 7.00 & 86.42 & 96.01 & 4403.90 & 9473.30 \\
\hline $201-300$ & 6.45 & 2.54 & 92.87 & 98.55 & 2164.60 & 3434.90 \\
\hline $301-400$ & 3.68 & 1.06 & 96.56 & 99.61 & 1234.70 & 1433.70 \\
\hline $401-500$ & 2.28 & 0.39 & 98.83 & 100.00 & 763.70 & 527.50 \\
\hline $501-600$ & 1.11 & & 99.94 & & 372.50 & 3.40 \\
\hline $601-700$ & 0.06 & & 100.00 & & 19.30 & \\
\hline Total for all firms & 100.00 & 100.00 & 100.00 & 100.00 & 33544.50 & 135253.20 \\
\hline Number of firms & & & & & 620 & 504 \\
\hline \multicolumn{7}{|c|}{ Panel B: Concentration of total ₹ dividends paid by Standalone Indian firms in 1995 to 2013} \\
\hline \multirow[t]{2}{*}{ Dividend ranking } & \multicolumn{2}{|c|}{$\begin{array}{l}\text { Percent of total } \\
\text { dividends }(\%)\end{array}$} & \multicolumn{2}{|c|}{$\begin{array}{c}\text { Cumulative } \% \text { of total } \\
\text { dividends }(\%)\end{array}$} & \multicolumn{2}{|c|}{$\begin{array}{c}\text { Real dividends } \\
\text { (₹ million, } 1995 \text { base) }\end{array}$} \\
\hline & 1995 & 2013 & 1995 & 2013 & 1995 & 2013 \\
\hline Top 100 & 92.48 & 98.84 & 92.48 & 98.84 & 5124.30 & 37360.80 \\
\hline
\end{tabular}




\begin{tabular}{|c|c|c|c|c|c|c|}
\hline $101-200$ & 7.52 & 1.16 & 100.00 & 100.00 & 416.50 & 438.10 \\
\hline $\begin{array}{l}\text { Total for all Standalone Indian } \\
\text { firms }\end{array}$ & 100.00 & 100.00 & 100.00 & 100.00 & 5540.80 & 37798.80 \\
\hline $\begin{array}{c}\text { Number of Standalone Indian } \\
\text { firms }\end{array}$ & & & & & 200 & 168.00 \\
\hline \multicolumn{7}{|c|}{ Panel C: Concentration of total ₹ dividends paid by Business Group Affiliated Indian firms in 1995 to 2013} \\
\hline \multirow[t]{2}{*}{ Dividend ranking } & \multicolumn{2}{|c|}{$\begin{array}{l}\text { Percent of total } \\
\text { dividends }(\%)\end{array}$} & \multicolumn{2}{|c|}{$\begin{array}{c}\text { Cumulative } \% \text { of total } \\
\text { dividends }(\%)\end{array}$} & \multicolumn{2}{|c|}{$\begin{array}{c}\text { Real dividends } \\
\text { (₹ million, } 1995 \text { base) }\end{array}$} \\
\hline & 1995 & 2013 & 1995 & 2013 & 1995 & 2013 \\
\hline Top 100 & 78.08 & 91.76 & 78.08 & 91.76 & 21868.90 & 89421.10 \\
\hline $101-200$ & 13.53 & 6.41 & 91.61 & 98.17 & 3788.60 & 6251.20 \\
\hline $201-300$ & 5.68 & 1.67 & 97.29 & 99.84 & 1589.70 & 1630.40 \\
\hline $301-400$ & 2.57 & 0.16 & 99.85 & 100.00 & 719.10 & 151.60 \\
\hline $401-500$ & 0.13 & & 100.00 & & 37.40 & \\
\hline $\begin{array}{l}\text { Total for all Business Group } \\
\text { Affiliated Indian firms }\end{array}$ & 100.00 & 100.00 & 100.00 & 100.00 & 28003.70 & 97454.30 \\
\hline $\begin{array}{l}\text { Number of Business Group } \\
\text { Affiliated Indian firms }\end{array}$ & & & & & 420 & 336 \\
\hline
\end{tabular}

\subsubsection{Cross-Sectional Distribution of Dividend Payments}

We further analyze the concentration of dividends by studying the cross-sectional distribution of dividends. Table 4 outlines the cross-sectional distribution of dividends in 1995 and in 2013, with the dividend payers grouped by the real ₹ dividends paid, ranging from greater than equal to ₹ 1000 million to less than ₹ 10 million. At the bottom of each panel A, B and $\mathrm{C}$ the payers are grouped into high-end and low-end firms based on the dividends distributed. The table depicts that the numbers of dividend paying firms ( $₹ 100$ million and above) increased from 64 in 1995 to 138 in 2013 with ₹ 103757.20 million increase in real dividends by 480.34 per cent.

At the same time the numbers of dividend payers in low-end sub-samples paying less than ₹ 50 million dividends increased by 91 firms but the real dividends paid decreased by ₹ 
1857.20 million. This result suggests that the number of dividend paying firms and the amount distributed thereby increased in top category dividend payers, while it decreased in bottom category payers. Thus, the decrease in the dividend paying firms followed by an increase in aggregate dividends, reflects that the high-end firms now dominates the dividend supply while the low-end firms have little influence on the dividends supply. These findings are similar across the various forms of corporate organizational structure too. The dividend paying firms in the high-end sub-samples as well as the amount distributed by these firms has increased for both the standalone and the business group affiliated firms from 1995 to 2013. While the number and the amount distributed decreased for the low-end sub-samples for both the organizational forms. This led to the emergence of two groups in the supply of aggregate dividends where one group with fewer firms supplying large amount of dividends and other group with large numbers of firms, supplying lesser amount of dividends.

Black and Scholes (1974) and Miller (1977) dispute that what issues to shareholders is the aggregate supply of the securities with specific features (e.g. dividends, taxable interest returns, etc.) and not the number of firms supplying those securities or the quantity supplied by individual firms. In their view, the decrease in number of dividend paying firms is of little significance as long as sufficient dividends are supplied to meet the demand of investors. Overall, the results are consistent with the findings of DeAngelo, et al. (2004) for the U.S. and Ferris, et al., (2006) for the U.K. capital markets.

Table 4. Cross-sectional analysis of dividend payments. Number of firms and real amount of dividend paid in 1995 and in 2013 in ₹ million. The nominal value of dividends is converted into real value by using GDP deflator with 1995 year as base

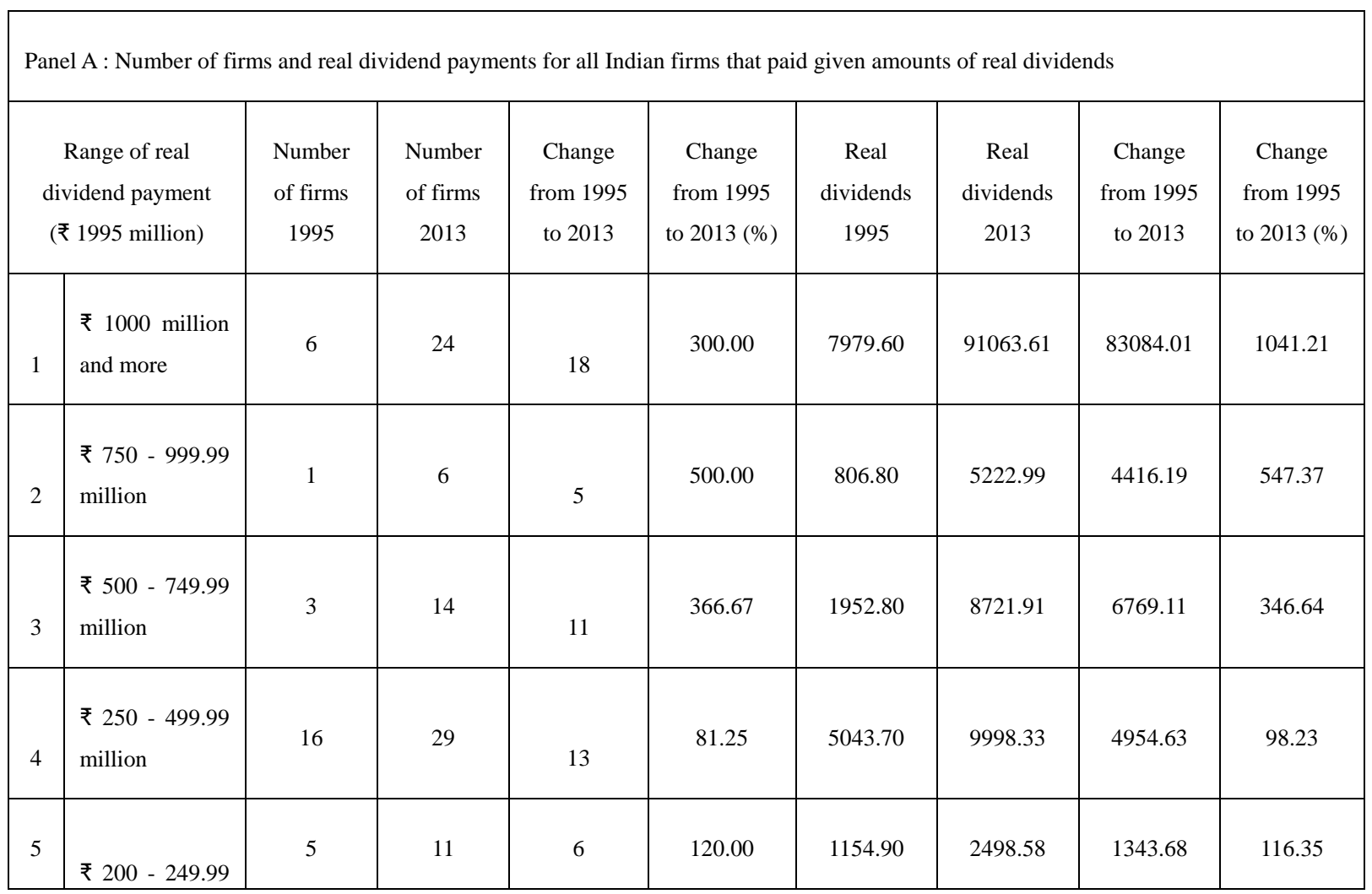




\begin{tabular}{|c|c|c|c|c|c|c|c|c|c|}
\hline & million & & & & & & & & \\
\hline 6 & $\begin{array}{l}₹ 150-199.99 \\
\text { million }\end{array}$ & 12 & 18 & 6 & 50.00 & 2119.10 & 3181.91 & 1062.81 & 50.15 \\
\hline 7 & $\begin{array}{l}₹ 100-149.99 \\
\text { million }\end{array}$ & 21 & 36 & 15 & 71.43 & 2543.70 & 4670.52 & 2126.82 & 83.61 \\
\hline 8 & $\begin{array}{l}₹ 50-99.99 \\
\text { million }\end{array}$ & 69 & 65 & -4 & -5.80 & 4842.10 & 4650.69 & -191.41 & -3.95 \\
\hline 9 & $\begin{array}{l}₹ 10-49.99 \\
\text { million }\end{array}$ & 261 & 193 & -68 & -26.05 & 5887.70 & 4677.33 & -1210.37 & -20.56 \\
\hline 10 & $\begin{array}{l}\text { ₹ Less than } 10 \\
\text { million }\end{array}$ & 226 & 385 & 159 & 70.35 & 1214.10 & 567.29 & -646.81 & -53.27 \\
\hline & Total & 620 & 504 & -116 & -19 & 33545 & 135253 & 101709 & 303 \\
\hline & $\begin{array}{l}₹ 100 \text { million } \\
\text { and above }\end{array}$ & 64 & 138 & 74 & 115.63 & 21600.60 & 125357.85 & 103757.25 & 480.34 \\
\hline & $\begin{array}{l}\text { Less than ₹ } \\
100 \text { million }\end{array}$ & 556 & 643 & 87 & 15.65 & 11943.90 & 9895.31 & -2048.59 & -17.15 \\
\hline & $\begin{array}{l}\text { Less than ₹ } 50 \\
\text { million }\end{array}$ & 487 & 578 & 91 & 18.69 & 7101.80 & 5244.62 & -1857.18 & -26.15 \\
\hline & Number of In & $\operatorname{lan} S \tan$ & firms & neir real divic & nd payments & & & & \\
\hline & $\begin{array}{l}\text { Range of real } \\
\text { vidend payment } \\
1995 \text { million) }\end{array}$ & $\begin{array}{c}\text { Number } \\
\text { of firms } \\
1995\end{array}$ & $\begin{array}{c}\text { Number } \\
\text { of firms } \\
2013\end{array}$ & $\begin{array}{l}\text { Change } \\
\text { from } 1995 \\
\text { to } 2013\end{array}$ & $\begin{array}{l}\text { Change } \\
\text { from } 1995 \\
\text { to } 2013(\%)\end{array}$ & $\begin{array}{c}\text { Real } \\
\text { dividends } \\
1995\end{array}$ & $\begin{array}{c}\text { Real } \\
\text { dividends } \\
2013\end{array}$ & $\begin{array}{l}\text { Change } \\
\text { from } 1995 \\
\text { to } 2013\end{array}$ & $\begin{array}{c}\text { Change } \\
\text { from } 1995 \\
\text { to } 2013(\%)\end{array}$ \\
\hline 1 & $\begin{array}{l}₹ 1000 \text { million } \\
\text { and more }\end{array}$ & 1 & 6 & 5.00 & 500.00 & 1335.60 & 28178.54 & 26842.94 & 2009.80 \\
\hline 2 & $\begin{array}{l}₹ 750-999.99 \\
\text { million }\end{array}$ & 0 & 1 & 1.00 & 0.00 & 0.00 & 839.24 & 839.24 & 0.00 \\
\hline 3 & $\begin{array}{l}₹ 500-749.99 \\
\text { million }\end{array}$ & 1 & 3 & 2.00 & 200.00 & 611.20 & 1857.53 & 1246.33 & 203.92 \\
\hline 4 & $\begin{array}{l}₹ 250-499.99 \\
\text { million }\end{array}$ & 2 & 6 & 4.00 & 200.00 & 610.90 & 2067.12 & 1456.22 & 238.37 \\
\hline
\end{tabular}




\begin{tabular}{|c|c|c|c|c|c|c|c|c|c|}
\hline 5 & $\begin{array}{l}₹ 200-249.99 \\
\text { million }\end{array}$ & 0 & 2 & 2.00 & 0.00 & 0.00 & 422.26 & 422.26 & 0.00 \\
\hline 6 & $\begin{array}{l}₹ 150-199.99 \\
\text { million }\end{array}$ & 2 & 2 & 0.00 & 0.00 & 354.60 & 369.03 & 14.43 & 4.07 \\
\hline 7 & $\begin{array}{l}₹ 100-149.99 \\
\text { million }\end{array}$ & 1 & 11 & 10.00 & 1000.00 & 110.50 & 1443.40 & 1332.90 & 1206.25 \\
\hline 8 & $\begin{array}{l}₹ 50-99.99 \\
\text { million }\end{array}$ & 8 & 11 & 3.00 & 37.50 & 596.30 & 734.58 & 138.28 & 23.19 \\
\hline 9 & $\begin{array}{l}₹ 10-49.99 \\
\text { million }\end{array}$ & 70 & 72 & 2.00 & 2.86 & 1372.20 & 1615.73 & 243.53 & 17.75 \\
\hline 10 & $\begin{array}{l}\text { ₹ Less than } 10 \\
\text { million }\end{array}$ & 115 & 54 & -61.00 & -53.04 & 549.50 & 271.39 & -278.11 & -50.61 \\
\hline & Total & 200 & 168 & -32.00 & -16.00 & 5540.80 & 37798.82 & 32258.02 & 582.19 \\
\hline & $\begin{array}{l}₹ 100 \text { million } \\
\text { and above }\end{array}$ & 7 & 31 & 24.00 & 342.86 & 3022.80 & 35177.12 & 32154.32 & 1063.73 \\
\hline & $\begin{array}{l}\text { Less than ₹ } \\
100 \text { million }\end{array}$ & 193 & 257 & 64.00 & 33.16 & 2518.00 & 2621.70 & 103.70 & 4.12 \\
\hline & $\begin{array}{l}\text { Less than ₹ } 50 \\
\text { million }\end{array}$ & 185 & 246 & 61.00 & 32.97 & 1921.70 & 1887.12 & -34.58 & -1.80 \\
\hline $\mathrm{Pa}$ & $\mathrm{C}:$ Number of $\mathrm{Ir}$ & n Busin & Group Af & ted firms anc & heir real divic & d payments & & & \\
\hline & $\begin{array}{l}\text { Range of real } \\
\text { vidend payment } \\
1995 \text { million) }\end{array}$ & $\begin{array}{c}\text { Number } \\
\text { of firms } \\
1995\end{array}$ & $\begin{array}{c}\text { Number } \\
\text { of firms } \\
2013\end{array}$ & $\begin{array}{c}\text { Change } \\
\text { from } 1995 \\
\text { to } 2013\end{array}$ & $\begin{array}{c}\text { Change } \\
\text { from } 1995 \\
\text { to } 2013(\%)\end{array}$ & $\begin{array}{c}\text { Real } \\
\text { dividends } \\
1995\end{array}$ & $\begin{array}{c}\text { Real } \\
\text { dividends } \\
2013\end{array}$ & $\begin{array}{l}\text { Change } \\
\text { from } 1995 \\
\text { to } 2013\end{array}$ & $\begin{array}{c}\text { Change } \\
\text { from } 1995 \\
\text { to } 2013(\%)\end{array}$ \\
\hline 1 & $\begin{array}{l}₹ 1000 \text { million } \\
\text { and more }\end{array}$ & 5 & 18 & 13.00 & 260.00 & 6644.00 & 62885.07 & 56241.07 & 846.49 \\
\hline 2 & $\begin{array}{l}\text { ₹ } 750 \text { - } 999.99 \\
\text { million }\end{array}$ & 1 & 5 & 4.00 & 400.00 & 806.80 & 4383.75 & 3576.95 & 443.35 \\
\hline 3 & $\begin{array}{l}₹ 500-749.99 \\
\text { million }\end{array}$ & 2 & 11 & 9.00 & 450.00 & 1341.60 & 6864.38 & 5522.78 & 411.66 \\
\hline
\end{tabular}




\begin{tabular}{|c|c|c|c|c|c|c|c|c|c|}
\hline 4 & $\begin{array}{l}₹ 250-499.99 \\
\text { million }\end{array}$ & 14 & 23 & 9.00 & 64.29 & 4432.80 & 7931.22 & 3498.42 & 78.92 \\
\hline 5 & $\begin{array}{l}₹ 200-249.99 \\
\text { million }\end{array}$ & 5 & 9 & 4.00 & 80.00 & 1154.90 & 2076.32 & 921.42 & 79.78 \\
\hline 6 & $\begin{array}{l}₹ 150-199.99 \\
\text { million }\end{array}$ & 10 & 16 & 6.00 & 60.00 & 1764.50 & 2812.88 & 1048.38 & 59.42 \\
\hline 7 & $\begin{array}{l}₹ 100-149.99 \\
\text { million }\end{array}$ & 20 & 25 & 5.00 & 25.00 & 2433.20 & 3227.12 & 793.92 & 32.63 \\
\hline 8 & $\begin{array}{l}₹ 50-99.99 \\
\text { million }\end{array}$ & 61 & 54 & -7.00 & -11.48 & 4245.80 & 3916.11 & -329.69 & -7.77 \\
\hline 9 & $\begin{array}{l}₹ 10-49.99 \\
\text { million }\end{array}$ & 191 & 121 & -70.00 & -36.65 & 4515.50 & 3061.60 & -1453.90 & -32.20 \\
\hline 10 & $\begin{array}{l}\text { ₹ Less than } 10 \\
\text { million }\end{array}$ & 111 & 54 & -57.00 & -51.35 & 664.60 & 295.90 & -368.70 & -55.48 \\
\hline & Total & 420 & 336 & -84.00 & -20.00 & 28003.70 & 97454.34 & 69450.64 & 248.01 \\
\hline & $\begin{array}{l}₹ 100 \text { million } \\
\text { and above }\end{array}$ & 57 & 107 & 50.00 & 87.72 & 18577.80 & 90180.73 & 71602.93 & 385.42 \\
\hline & $\begin{array}{l}\text { Less than ₹ } \\
100 \text { million }\end{array}$ & 363 & 386 & 23.00 & 6.34 & 9425.90 & 7273.61 & -2152.29 & -22.83 \\
\hline & $\begin{array}{l}\text { Less than ₹ } 50 \\
\text { million }\end{array}$ & 302 & 332 & 30.00 & 9.93 & 5180.10 & 3357.50 & -1822.60 & -35.18 \\
\hline
\end{tabular}

\subsection{Relationship between Dividends and Earnings}

\subsubsection{Earnings Concentration among Dividend Paying Firms}

The researchers such as Lintner (1956), Fama and Babiak (1968) and DeAngelo et al. (2004) suggests that the key factor affecting the dividend payments decision is firm's earning. This indicates that the dividend concentration and the considerable increase in it over the last two decades in Indian capital markets might be due to the analogous concentration in earnings. In this section, we investigate the relation between dividends and earnings and the extent to which the corporate earnings explain the dividends behavior of Indian firms.

The dividend paying firms are ranked from the largest to smallest as per the total dividends paid in 1995 and in 2013. The table 5 reports the percentage of total earnings accounted by 
the top 100 dividend payers, the next largest 100 payers, and so on. Like dividends, earnings too concentrated among fewer firms in 1995 and this concentration increased considerably among the dividend paying firms over the last two decades. In 1995, the top 100 dividend paying firms contributed 66.89 per cent of total earnings of all dividend payers during that year, while cumulatively top 200 dividend payers contributed 82.60 per cent. The corresponding percentage for 2013 is 81.47 per cent and 91.79 per cent. The real earnings increased greatly for top 100 dividend payers from ₹. 84152.40 million in 1995 to ₹. 387828.10 million in 2013.

The earnings of top 100 dividend paying firms concentrated too for the standalone and business group affiliated firms and these earnings increased noticeably over the last two decades. While at the same time the earnings of the smallest dividend paying firms generated either very low or zero earnings in 1995 and in 2013 for all sample Indian firms as well as for both the standalone and business group affiliated firms. Thus, we conclude that the earnings concentration in Table 5 accompany the dividend concentration as noted in Table 3.

Table 5. Concentration of earnings of dividend paying firms among the Indian firms and the corporate organizational form in 1995 and in 2013

\begin{tabular}{|c|c|c|c|c|c|c|}
\hline \multicolumn{7}{|c|}{ Panel A : Concentration of earnings among 781 sample Indian firms in 1995 and in 2013} \\
\hline \multirow[t]{2}{*}{$\begin{array}{l}\text { Dividend } \\
\text { ranking }\end{array}$} & \multicolumn{2}{|c|}{$\begin{array}{l}\text { Percent of total earnings of } \\
\text { dividend-paying Indian firms } \\
\qquad(\%)\end{array}$} & \multicolumn{2}{|c|}{$\begin{array}{l}\text { Cumulative } \% \text { of total earnings of } \\
\text { dividend-paying Indian firms }(\%)\end{array}$} & \multicolumn{2}{|c|}{$\begin{array}{l}\text { Real earnings } \\
\text { (₹ million, } 1995 \\
\text { base) }\end{array}$} \\
\hline & 1995 & 2013 & 1995 & 2013 & 1995 & 2013 \\
\hline Top 100 & 66.89 & 81.47 & 66.89 & 81.47 & 84152.40 & 387828.06 \\
\hline $101-200$ & 15.71 & 10.33 & 82.60 & 91.79 & 19758.10 & 49161.91 \\
\hline $201-300$ & 7.67 & 5.74 & 90.28 & 97.54 & 9654.20 & 27333.16 \\
\hline $301-400$ & 4.89 & 1.74 & 95.17 & 99.28 & 6153.20 & 8284.93 \\
\hline $401-500$ & 3.12 & 0.72 & 98.29 & 100.00 & 3924.10 & 3430.94 \\
\hline $501-600$ & 1.46 & 0.00 & 99.75 & 100.00 & 1839.40 & 18.37 \\
\hline $601-700$ & 0.25 & & 100.00 & & 316.80 & \\
\hline $\begin{array}{l}\text { Total for all } \\
\text { firms paying } \\
\text { dividends }\end{array}$ & 100.00 & 100.00 & 100.00 & 100.00 & 125798.20 & 476057.36 \\
\hline
\end{tabular}




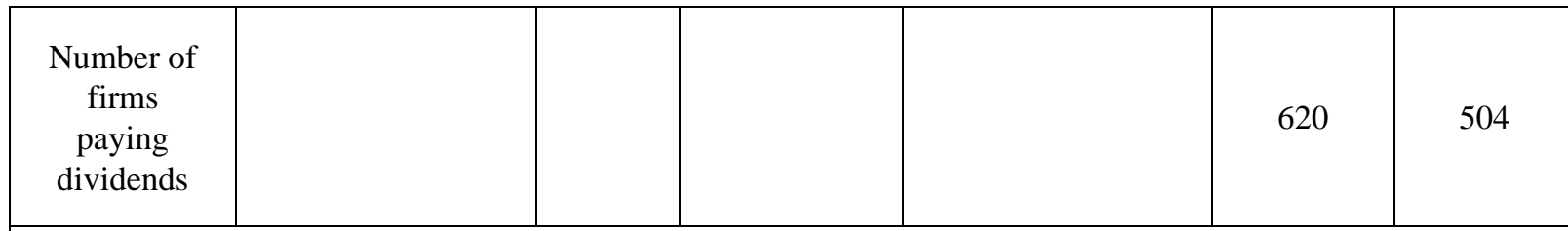

Panel B : Concentration of earnings among Standalone Indian firms in 1995 and in 2013

\begin{tabular}{|c|c|c|c|c|c|c|}
\hline \multirow[t]{2}{*}{$\begin{array}{l}\text { Dividend } \\
\text { ranking }\end{array}$} & \multicolumn{2}{|c|}{$\begin{array}{l}\text { Percent of total earnings of } \\
\text { dividend-paying Standalone Indian } \\
\text { firms }(\%)\end{array}$} & \multicolumn{2}{|c|}{$\begin{array}{c}\text { Cumulative } \% \text { of total } \\
\text { earnings of dividend-paying } \\
\text { Standalone Indian firms }(\%)\end{array}$} & \multicolumn{2}{|c|}{$\begin{array}{l}\text { Real earnings } \\
\text { (₹ million, } 1995 \\
\text { base) }\end{array}$} \\
\hline & 1995 & 2013 & 1995 & 2013 & 1995 & 2013 \\
\hline Top 100 & 89.20 & 89.06 & 89.20 & 89.06 & 16371.30 & 105437.10 \\
\hline $101-200$ & 10.80 & 10.94 & 100.00 & 100.00 & 1982.60 & 12951.50 \\
\hline $\begin{array}{l}\text { Total for all } \\
\text { Standalone } \\
\text { firms paying } \\
\text { dividends }\end{array}$ & 100.00 & 100.00 & 100.00 & 100.00 & 18353.90 & 118388.65 \\
\hline $\begin{array}{l}\text { Number of } \\
\text { Standalone } \\
\text { firms } \\
\text { paying } \\
\text { dividends }\end{array}$ & & & & & 288 & 168 \\
\hline
\end{tabular}

Panel C : Concentration of earnings among Business Group Affiliated Indian firms in 1995 and in 2013

\begin{tabular}{|c|c|c|c|c|c|c|}
\hline \multirow{2}{*}{$\begin{array}{c}\text { Dividend } \\
\text { ranking }\end{array}$} & \multicolumn{2}{|c|}{$\begin{array}{c}\text { Percent of total earnings of } \\
\text { dividend-paying Business Group } \\
\text { Affiliated Indian firms (\%) }\end{array}$} & $\begin{array}{c}\text { Cumulative \% of total earnings } \\
\text { of dividend-paying Business } \\
\text { Group Affiliated Indian firms } \\
(\%)\end{array}$ & \multicolumn{2}{c|}{$\begin{array}{c}\text { Real earnings } \\
\text { (₹ million, 1995 base) }\end{array}$} \\
\cline { 2 - 7 } & 1995 & 2013 & 1995 & 2013 & 1995 & 2013 \\
\hline Top 100 & 72.39 & 87.78 & 72.39 & 87.78 & 77784.10 & 313944.40 \\
\hline $101-200$ & 16.62 & 9.67 & 89.02 & 97.45 & 17857.50 & 34585.90 \\
\hline $201-300$ & 7.08 & 2.45 & 96.10 & 99.90 & 7607.20 & 8776.80 \\
\hline $301-400$ & 3.54 & 0.10 & 99.64 & 100.00 & 3804.30 & 361.60 \\
\hline $401-500$ & 100.00 & 100.00 & 100.00 & 100.00 & 107444.30 & 357668.72 \\
\hline Total for all
\end{tabular}




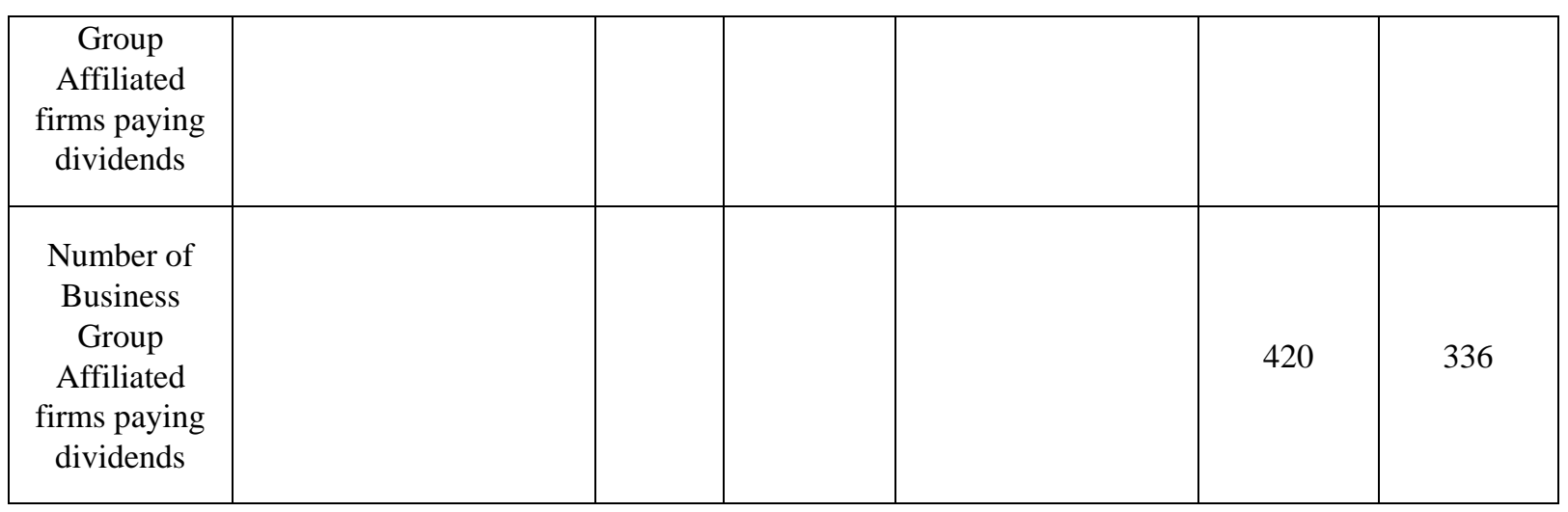

Note: The dividend paying firms are ranked from the largest to smallest as per the total dividends paid in each year. The table reports the percentage of total earnings accounted by the top 100 dividend payers, the next largest 100 payers, and so on. A firm's dividends and earnings are the amounts declared for the financial year ending in that year.

\subsubsection{The Pooled Earnings Distribution of Dividend Payers and Non-Payers}

We analyze the earnings distribution of dividend paying and non-paying firms combined together. Lintner (1956) found that the manager of a firm sets the dividend payout ratio in consideration with the long-run earnings of a firm rather than a firm's current year's earnings. Thus, the five-year average real earnings better reflects the firm's ability to pay dividends than one year current earnings. In Table 6 panel $\mathrm{A}, \mathrm{B}$ and $\mathrm{C}$ reports the cross-sectional distributions of five-year average real earnings for sample Indian firms, standalone firms and business group affiliated firms (payers and non-payers) combined, ending in 1995 and in 2013. In panel A, we observe that the total positive earnings increased from ₹ . 76565 million in 1995 to ₹ 526788.90 million in 2013 by 85.47 per cent. There are 9 firms in top earnings range in 2013 and these firms represent around 44.42 per cent of total positive earnings of all the firms. The earnings of the 20 firms in the first two top earners category represents 59.47 per cent of earnings of total positive earnings and it is more than half of the earnings of all the sample firms combined together in 2013. Whereas, there are no firms in these two top earners category in the year 1995 .

The numbers of firms with negative earnings increased from 45 in 1995 to 147 in 2013 and the amount of negative earnings represents 1.73 per cent in 1995 and 4.77 per cent in 2013 of total positive earnings. This conveys that the negative earnings of firms has impact on the dividend payment decision among Indian firms consistent with the U.S. capital markets, where losses led to the dividend cuts and omissions (DeAngelo and DeAngelo, 1990 and DeAngelo, DeAngelo and Skinner, 1992). The number of firms, from the top third earners category to the lowest bottom earners category increased gradually, with the highest numbers of firms in the lowest bottom earnings category with ₹ . 0 to 100 million earnings for both the years 1995 and 2013. This suggests that there is concentration in earnings and this concentration increased considerably over the last two decades with small numbers of firms representing large proportion of earnings for sample Indian firms. 
In panel B there are 2 standalone firms in the top earnings category in 2013 which represents 47.28 per cent of total positive earnings of all standalone firms during that year. The earnings of 3 standalone firms in the top two earnings range represents 55.08 per cent of earnings in 2013 with no firms in the year 1995. The firms with negative earnings increased from 18 to 66 with losses ₹. 164.50 million and ₹. 8485.90 million in 1995 and in 2013 respectively. The total positive earnings increased from ₹ . 10969.30 million in 1995 to ₹. 111942.80 million in 2013 by 90.20 per cent for the standalone firms. Although these increase in aggregate earnings amount is much smaller for standalone firms as compared to Business Group Affiliated firms but percentage wise this increase is comparatively greater from 1995 to 2013.

In panel $\mathrm{C}$ there are more numbers of firms in first top and second top earnings category for business group affiliated firms as compared to standalone firms in 2013. The earnings of firms in top two earnings category represents almost 60.61 per cent of total positive earnings of the entire business group affiliated firms in 2013. The negative earnings increased from $₹$. 1136.30 million to ₹ . 15499.10 million which represents just 1.76 per cent and 3.88 per cent of total earnings in 1995 and in 2013 respectively. The total positive earnings of business group affiliated firms increased from ₹ . 65595.60 million in 1995 to ₹ . 414846.20 million in 2013 by 84.19 per cent.

Table 6. Cross-sectional distribution of firm's real earnings in 1995 and in 2013

\begin{tabular}{|c|c|c|c|c|c|c|c|}
\hline \multicolumn{8}{|c|}{ Panel A : Cross-sectional distributions of five-year average real earnings for Indian firms ending in 1995 and in 2013} \\
\hline \multirow[t]{2}{*}{ Sr. No. } & \multirow[t]{2}{*}{$\begin{array}{l}\text { Five year average real earnings } \\
(₹ 1995)\end{array}$} & \multicolumn{2}{|c|}{$\begin{array}{l}\text { Number of } \\
\text { firms }\end{array}$} & \multicolumn{2}{|c|}{$\begin{array}{l}\text { Real earnings } \\
\text { (₹ million) }\end{array}$} & \multicolumn{2}{|c|}{$\begin{array}{c}\text { Real earnings as a } \% \text { of } \\
\text { total }(\%)\end{array}$} \\
\hline & & 1995 & 2013 & 1995 & 2013 & 1995 & 2013 \\
\hline 1 & $₹ 10000$ million or greater & 0 & 9 & 0.00 & 223332.84 & 0.00 & 44.42 \\
\hline 2 & $₹ 5000-10000$ million & 0 & 11 & 0.00 & 75679.66 & 0.00 & 15.05 \\
\hline 3 & $₹ 2500$ - 5000 million & 1 & 13 & 4721.63 & 45093.34 & 6.27 & 8.97 \\
\hline 4 & $₹ \quad 1000-2500$ million & 12 & 50 & 19559.19 & 76344.55 & 25.99 & 15.18 \\
\hline 5 & $₹ 500-1000$ million & 15 & 59 & 10131.09 & 41941.24 & 13.46 & 8.34 \\
\hline 6 & $₹ 250-500$ million & 40 & 87 & 12829.75 & 30989.14 & 17.05 & 6.16 \\
\hline 7 & $₹ \quad 100-250$ million & 95 & 138 & 14625.63 & 22528.50 & 19.43 & 4.48 \\
\hline
\end{tabular}




\begin{tabular}{|c|c|c|c|c|c|c|c|c|c|}
\hline 8 & $₹ \quad 0-100$ million & 573 & 267 & \multicolumn{2}{|c|}{14697.69} & \multicolumn{2}{|c|}{10879.64} & 19.53 & 2.16 \\
\hline \multirow[t]{3}{*}{9} & Negative earnings & 45 & 147 & \multicolumn{2}{|c|}{-1300.83} & \multicolumn{2}{|c|}{-23984.94} & -1.73 & -4.77 \\
\hline & Total & 781 & 781 & 75264.14 & \multicolumn{2}{|c|}{502803.97} & \multicolumn{2}{|c|}{100.00} & 100.00 \\
\hline & Total positive earnings only & 736 & 634 & 76564.98 & \multicolumn{2}{|c|}{526788.91} & & & \\
\hline
\end{tabular}

Panel B : Cross-sectional distributions of five-year average real earnings for Indian Standalone firms

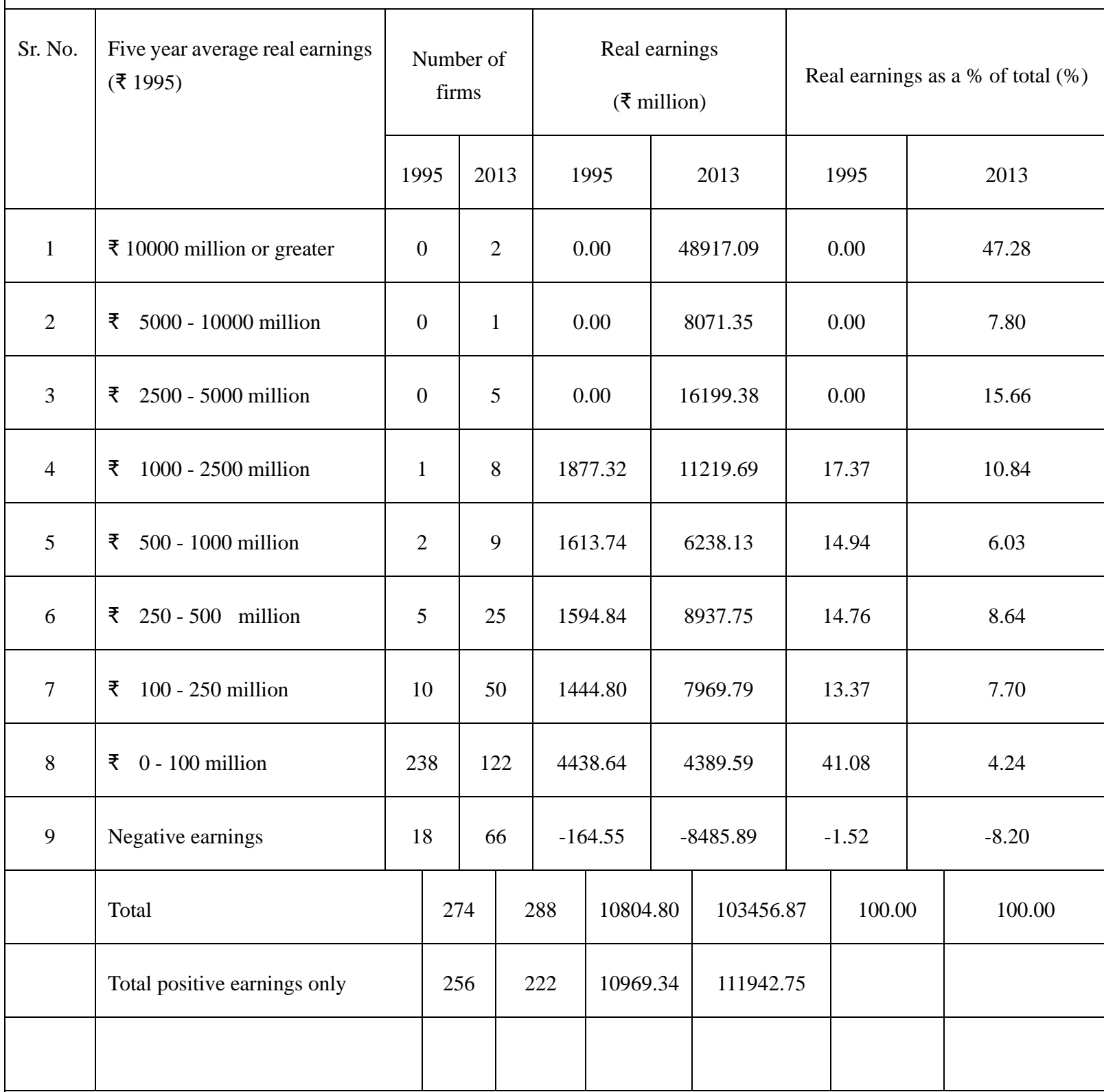

Panel C : Cross-sectional distributions of five-year average real earnings for Indian Business Group Affiliated firms

\begin{tabular}{|l|l|l|l|l}
\hline Sr. No. & $\begin{array}{l}\text { Five year average real earnings }(₹ \\
1995)\end{array}$ & $\begin{array}{c}\text { Number of } \\
\text { firms }\end{array}$ & Real earnings & $\begin{array}{c}\text { Real earnings as a of total } \\
(\%)\end{array}$
\end{tabular}




\begin{tabular}{|c|c|c|c|c|c|c|c|}
\hline & & & & \multicolumn{2}{|c|}{ (₹ million) } & \multirow[b]{2}{*}{1995} & \multirow[b]{2}{*}{2013} \\
\hline & & 1995 & 2013 & 1995 & 2013 & & \\
\hline 1 & $₹ \quad 10000$ million or greater & 0 & 7 & 0.00 & 174415.75 & 0.00 & 43.68 \\
\hline 2 & $₹ 5000-10000$ million & 0 & 10 & 0.00 & 67608.31 & 0.00 & 16.93 \\
\hline 3 & $₹ 2500-5000$ million & 1 & 8 & 4721.63 & 28893.96 & 7.32 & 7.24 \\
\hline 4 & $₹ \quad 1000-2500$ million & 11 & 42 & 17681.87 & 65124.86 & 27.43 & 16.31 \\
\hline 5 & $₹ 500-1000$ million & 13 & 50 & 8517.35 & 35703.11 & 13.21 & 8.94 \\
\hline 6 & $₹ 250-500$ million & 35 & 62 & 11234.91 & 22051.39927 & 17.43 & 5.52 \\
\hline 7 & $₹ \quad 100-250$ million & 85 & 88 & 13180.83 & 14558.70 & 20.45 & 3.65 \\
\hline 8 & $₹ 0-100$ million & 321 & 145 & 10259.05 & 6490.06 & 15.92 & 1.63 \\
\hline 9 & Negative earnings & 27 & 81 & -1136.29 & -15499.05 & -1.76 & -3.88 \\
\hline & Total & 493 & 493 & 64459.35 & 399347.11 & 100.00 & 100.00 \\
\hline & Total positive earnings only & 461 & 412 & 65595.63 & 414846.16 & & \\
\hline
\end{tabular}

Note: The table reports the distribution of five-year average real earnings ending in 1995 and in 2013. For example the figure in 2013 is obtained as the average of real earnings over the five years from 2009 to 2013 . The nominal earnings are converted into real earnings by using GDP deflator with 1995 year as base. The dividends and earnings are the amount declared at the end of financial year in 1995 or 2013.

\subsubsection{The Separate Earnings of Dividend Paying and Non-Dividend Paying Firms}

In Table 7 we partition the pooled distribution of five-year average real earnings from Table 6 between payers and non-payers to examine the impact of earnings and losses on the dividends payment and non-payment decisions of a firm. If we observe the "percentage from payers" column in panel A the dividend payers contributed major proportion of total earnings for all the earnings ranges with a high of 100 per cent to as low as 61.05 per cent in 2013 and 79.93 per cent in 1995.

The non-dividend paying firms suffered a loss of ₹ . 1298.10 million and ₹ . 23158.40 million which is 99.79 per cent and 96.55 per cent of 1995 and 2013 losses respectively. In panel A the number of non-payers in negative earnings category increased from 43 in 1995 to 138 in 
2013 and this number is quite large as compared to payers ( 2 in 1995 and 9 in 2013). This suggests that the losses occurred by the firms are the major reason for dividend cuts and omissions. There are 9 and 11 payers in the first top and second top earnings ranges and these 20 firms contributed 58.76 per cent of total earnings in 2013.

The results are similar across the standalone and business group affiliated firms in panel B and $\mathrm{C}$ respectively, where there are small number of dividend paying firms in top earnings category sharing major proportion of total earnings and large numbers of non-dividend paying firms in the negative earnings category in 1995 and in 2013. Thus, from above discussion we find a strong and positive relation between earnings and dividend payment decision and negative relation between losses and decision to pay for all sample Indian firms as well as for various forms of corporate organizational structure. Therefore, the firms with high levels of earnings are more likely to pay dividends while the firms with negative earnings are more likely to cut or omit dividends.

Table 7. Real earnings (₹ million) for Indian firms in 1995 and in 2013: Sample partitioned into dividend payers and non-payers

\begin{tabular}{|c|c|c|c|c|c|c|c|c|c|c|c|c|}
\hline \multirow{2}{*}{$\begin{array}{c}\text { Real } \\
\text { earnings } \\
\text { (1995 ₹ ) }\end{array}$} & \multicolumn{3}{|c|}{1995 Number of firms } & \multicolumn{3}{|c|}{2013 Number of firms } & \multicolumn{3}{|c|}{1995 Earnings ( $₹$ million) } & \multicolumn{3}{|c|}{2013 Real earnings (₹ million) } \\
\hline & Payers & $\begin{array}{c}\text { Non } \\
\text { payers }\end{array}$ & $\begin{array}{c}\% \text { tage } \\
\text { from } \\
\text { payers } \\
(\%)\end{array}$ & Payers & $\begin{array}{l}\text { Non } \\
\text { payers }\end{array}$ & $\begin{array}{l}\% \text { tage } \\
\text { from } \\
\text { payers } \\
(\%)\end{array}$ & Payers & $\begin{array}{c}\text { Non } \\
\text { payers }\end{array}$ & $\begin{array}{l}\% \text { tage } \\
\text { from } \\
\text { payers } \\
(\%)\end{array}$ & Payers & $\begin{array}{c}\text { Non } \\
\text { payers }\end{array}$ & $\begin{array}{c}\% \text { tage } \\
\text { from } \\
\text { payers } \\
(\%)\end{array}$ \\
\hline \multicolumn{13}{|c|}{ Panel A. Five-year average real earnings distribution for payers and non-payers ending in 1995 and in 2013} \\
\hline $\begin{array}{l}1 . \quad ₹ \\
10000 \\
\text { million } \\
\text { or greater }\end{array}$ & 0 & 0 & 0.00 & 9 & 0 & 100.00 & 0.00 & 0.00 & 0.00 & 223332.84 & 0.00 & 100 \\
\hline $\begin{array}{l}2 . \quad ₹ \\
5000 \quad- \\
10000 \\
\text { million }\end{array}$ & 0 & 0 & 0.00 & 11 & 0 & 100.00 & 0.00 & 0.00 & 0.00 & 75679.66 & 0.00 & 100 \\
\hline $\begin{array}{l}3 . \quad ₹ \\
2500 \quad- \\
5000 \\
\text { million }\end{array}$ & 1 & 0 & 100.00 & 12 & 1 & 92.31 & 4721.63 & 0.00 & 100.00 & 41543.58 & 3549.76 & 92.13 \\
\hline $\begin{array}{ll}4 . & ₹ \\
1000 & - \\
2500 & \end{array}$ & 12 & 0 & 100.00 & 49 & 1 & 98.00 & 19559.19 & 0.00 & 100.00 & 74417.50 & 1927.05 & 97.48 \\
\hline
\end{tabular}




\begin{tabular}{|c|c|c|c|c|c|c|c|c|c|c|c|c|}
\hline million & & & & & & & & & & & & \\
\hline $\begin{array}{l}5 . \quad ₹ \\
500 \quad- \\
1000 \\
\text { million }\end{array}$ & 14 & 1 & 93.33 & 56 & 3 & 94.92 & 9327.20 & 803.89 & 92.07 & 39989.67 & 1951.57 & 95.35 \\
\hline $\begin{array}{l}6 . \quad ₹ \\
250-500 \\
\text { million }\end{array}$ & 40 & 0 & 100.00 & 76 & 11 & 87.36 & 12829.75 & 0.00 & 100.00 & 27288.46 & 3700.68 & 88.06 \\
\hline $\begin{array}{l}7 . \quad ₹ \\
100-250 \\
\text { million }\end{array}$ & 93 & 2 & 97.89 & 119 & 19 & 86.23 & 14405.17 & 220.46 & 98.49 & 19498.19 & 3030.30 & 86.55 \\
\hline $\begin{array}{l}\text { 8. ₹ } 0 \text { - } \\
100 \\
\text { million }\end{array}$ & 458 & 115 & 79.93 & 163 & 104 & 61.05 & 753.00 & 1024.35 & 42.37 & 7977.13 & 2902.51 & 73.32 \\
\hline $\begin{array}{l}9 . \\
\text { Negative } \\
\text { earnings }\end{array}$ & 2 & 43 & 4.44 & 9 & 138 & 6.12 & -2.74 & -1298.09 & 0.21 & -826.51 & -23158.43 & 3.45 \\
\hline Total & 620 & 161 & 79.39 & 504 & 277 & 64.53 & 74784.89 & 750.61 & 99.01 & 508900.52 & -6096.55 & 101 \\
\hline
\end{tabular}

Panel B. Five-year average real earnings distribution for payers and non-payers ending in 1995 and in 2013 (Standalone Indian firms)

\begin{tabular}{|c|c|c|c|c|c|c|c|c|c|c|c|c|}
\hline $\begin{array}{l}1 . \\
10000 \\
\text { million } \\
\text { or greater }\end{array}$ & 0 & 0 & 0.00 & 2 & 0 & 100.00 & 0.00 & 0.00 & 0.00 & 48917.09 & 0.00 & 100 \\
\hline $\begin{array}{l}2 . \\
5000 \\
10000 \\
\text { million }\end{array}$ & 0 & 0 & 0.00 & 1 & 0 & 100.00 & 0.00 & 0.00 & 0.00 & 8071.35 & 0.00 & 100 \\
\hline $\begin{array}{l}3 . \\
2500 \\
5000 \\
\text { million }\end{array}$ & 0 & 0 & 0.00 & 4 & 1 & 80.00 & 0.00 & 0.00 & 0.00 & 12649.62 & 3549.76 & 78.09 \\
\hline $\begin{array}{l}4 . \\
1000 \\
2500\end{array}$ & 0 & 0 & 0.00 & 8 & 0 & 100.00 & 0.00 & 0.00 & 0.00 & 11219.69 & 0.00 & 100 \\
\hline
\end{tabular}




\begin{tabular}{|c|c|c|c|c|c|c|c|c|c|c|c|c|}
\hline million & & & & & & & & & & & & \\
\hline $\begin{array}{l}5 . \quad ₹ \\
500 \\
1000 \\
\text { million }\end{array}$ & 2 & 0 & 100.00 & 9 & 0 & 100.00 & 1613.74 & 1000.00 & 100.00 & 6238.13 & 0.00 & 100 \\
\hline $\begin{array}{ll}6 . ₹ \quad 250 \\
-\quad 500 \\
\text { million }\end{array}$ & 5 & 0 & 100.00 & 21 & 4 & 84.00 & 1594.84 & 1000.00 & 100.00 & 7770.03 & 1167.71 & 86.94 \\
\hline $\begin{array}{l}7 . \quad ₹ \\
100-250 \\
\text { million }\end{array}$ & 10 & 0 & 100.00 & 42 & 8 & 84.00 & 1444.80 & 1000.00 & 100.00 & 6707.97 & 1261.82 & 84.17 \\
\hline $\begin{array}{l}\text { 8. ₹ } 0 \text { - } \\
100 \\
\text { million }\end{array}$ & 182 & 70 & 72.22 & 77 & 45 & 63.11 & 3994.63 & 899.97 & 90.00 & 3380.32 & 1009.27 & 77.01 \\
\hline $\begin{array}{l}9 . \\
\text { Negative } \\
\text { earnings }\end{array}$ & 0 & 18 & 0.00 & 4 & 62 & 6.06 & 0.00 & 0.00 & 0.00 & -56.07 & -8429.82 & 0.66 \\
\hline Total & 200 & 88 & 69.44 & 168 & 120 & 58.33 & 10525.33 & 974.13 & 97.41 & 104898.12 & -1441.26 & 101 \\
\hline
\end{tabular}

Panel C. Five-year average real earnings distribution for payers and non-payers ending in 1995 and in 2013 (Business Group affiliated Indian firms )

\begin{tabular}{|c|c|c|c|c|c|c|c|c|c|c|c|c|}
\hline $\begin{array}{l}1 . \quad ₹ \\
10000 \\
\text { million } \\
\text { or greater }\end{array}$ & 0 & 0 & 0.00 & 7 & 0 & 100.00 & 0.00 & 0.00 & 0.00 & 174415.75 & 0.00 & 100 \\
\hline $\begin{array}{l}2 . \quad ₹ \\
5000 \quad- \\
10000 \\
\text { million }\end{array}$ & 0 & 0 & 0.00 & 10 & 0 & 100.00 & 0.00 & 0.00 & 0.00 & 67608.31 & 0.00 & 100 \\
\hline $\begin{array}{l}3 . \quad ₹ \\
2500 \quad- \\
5000 \\
\text { million }\end{array}$ & 1 & 0 & 100.00 & 8 & 0 & 100.00 & 4721.63 & 0.00 & 100.00 & 28893.96 & 0.00 & 100 \\
\hline $\begin{array}{ll}4 . & ₹ \\
1000 & - \\
2500 & \end{array}$ & 11 & 0 & 100.00 & 41 & 1 & 97.62 & 17681.87 & 0.00 & 100.00 & 63197.81 & 1927.05 & 97.04 \\
\hline
\end{tabular}




\begin{tabular}{|l|c|c|c|c|c|c|c|c|c|c|c|c|}
\hline million & & & & & & & & & & & & \\
\hline $\begin{array}{l}5 . \\
500 \\
1000 \\
\text { million }\end{array}$ & 12 & 1 & 92.31 & 47 & 3 & 94.00 & 7713.46 & 803.89 & 90.56 & 33751.54 & 1951.57 & 94.53 \\
\hline $\begin{array}{l}6 . \quad ₹ \\
250-500 \\
\text { million }\end{array}$ & 35 & 0 & 100.00 & 55 & 7 & 88.71 & 11234.91 & 0.00 & 100.00 & 19518.43 & 2532.97 & 88.51 \\
\hline $\begin{array}{l}7 . \\
100-250 \\
\text { million }\end{array}$ & 83 & 2 & 97.65 & 77 & 11 & 87.50 & 12960.37 & 220.46 & 98.33 & 12790.22 & 1768.48 & 87.85 \\
\hline $\begin{array}{l}8 . \text { ₹ } 0 \\
100 \\
\text { million }\end{array}$ & 276 & 45 & 85.98 & 86 & 59 & 59.31 & 9950.07 & 308.98 & 96.99 & 4596.82 & 1893.24 & 70.83 \\
\hline $\begin{array}{l}9 . \\
\text { Negative } \\
\text { earnings }\end{array}$ & 2 & 25 & 7.41 & 5 & 76 & 6.17 & -2.74 & -1133.5 & 0.24 & -770.45 & -14728.6 & 4.97 \\
\hline \begin{tabular}{l} 
Total \\
\hline
\end{tabular} & 420 & 73 & 85.19 & 336 & 157 & 68.15 & 64259.56 & 199.78 & 99.69 & 404002.40 & -4655.29 & 101 \\
\hline
\end{tabular}

Note: Panel A, B and C reports the pooled distribution of five-year average real earnings of Indian firms, Standalone firms and Business Group Affiliated firms respectively ending in 1995 and in 2013. The nominal real earnings are converted into real value by using GDP deflator with 1995 year as base and a firm's dividend and earnings are amounts declared in financial ending in 1995 or 2013. The column "percentage from payers" represents the percentage of total earnings of payers and non-payers contributed by the earnings of dividend paying firms.

\subsection{Aggregate Dividend Payout Ratio and the Propensity to Pay Dividends}

In this section we investigate whether the propensity to pay dividend has changed over the period of study. The term "propensity to pay dividends" indicates the capacity of firm to distribute its earnings in the form of dividends (DeAngelo, et al., 2004). While Fama and French (2001a) used the same term to express the number of dividend paying firms that changed during the period of study based on firm specific characteristics. Row 1 of Table 8 shows that the aggregate dividend payout ratio considering the total earnings of payers and non-payers in denominator increased, both when the current one-year earnings are used (from 25.77 per cent in 1995 to 31.59 per cent in 2013) and when five-year real earnings are used (from 44.57 per cent in 1995 to 77.47 per cent in 2013). Row 2 shows the payout ratio by considering the total earnings of payers in denominator. Row 3 depicts the median firm's 
payout ratio of dividend paying firms. Row 4 and 5 shows the same statistics for 442 firms that paid dividends in both 1995 and 2013.

Row 2 shows that the aggregate dividend payout ratio increased from 26.37 per cent to 28.41 per cent when we consider current one-year earnings and from 44.85 per cent to 76.54 per cent for five-year average real earnings. Row 3 and 5 shows that the median firm's payout ratio of dividend paying firms decreased in case of current one year earnings and increased for five-year average real earnings from 1995 to 2013 for 781 sample firms and 442 constant composition sample firms. Row 4 depicts that aggregate payout ratio of constant composition sample increased for both one-year earnings and five-year average real earnings from 1995 to 2013.

If we examine the aggregate dividend payout ratio for standalone and business group affiliated firms for Row 1, 2 and 4 it increased slightly from 1995 to 2013 when current one-year earnings are used. While it increased in greater extent for standalone firms as compared to business group affiliated firms from 1995 to 2013 when five-year average real earnings are used. The median firm's payout ratio in Row 3 and 5 for total sample and constant composition sample decreased slightly for standalone firms when both one-year and five-year average real earnings are considered. While it decreased slightly for one-year earnings and increased slightly for five-year average real earnings for business group affiliated firms from 1995 to 2013.

Overall, Table 8 suggests that the payout ratio didn't decline for all Indian firms as well as for standalone and business group affiliated firms, while it increased slightly over the last two decades. Thus, these results convey that there hasn't been reduced propensity to pay the dividends which is inconsistent with any global declining propensity to pay and is consistent with the findings of DeAngelo, et al. (2004) and Ferris, et al. (2006).

Table 8. Aggregate and median dividend payout ratios for Indian firms and corporate organizational forms from 1995 to 2013

\begin{tabular}{|c|c|c|c|c|c|c|c|c|c|c|c|c|c|}
\hline & \multirow{3}{*}{ Payout ratio measure } & \multicolumn{4}{|c|}{ Indian firms } & \multicolumn{4}{|c|}{ Standalone firms } & \multicolumn{4}{|c|}{ Business Group Affiliated firms } \\
\hline & & \multicolumn{2}{|c|}{$\begin{array}{c}\text { One-year } \\
\text { earnings (\%) }\end{array}$} & \multicolumn{2}{|c|}{$\begin{array}{l}\text { Five-year } \\
\text { average real } \\
\text { earnings (\%) }\end{array}$} & \multicolumn{2}{|c|}{$\begin{array}{c}\text { One-year } \\
\text { earnings }(\%)\end{array}$} & \multicolumn{2}{|c|}{$\begin{array}{l}\text { Five-year } \\
\text { average real } \\
\text { earnings (\%) }\end{array}$} & \multicolumn{2}{|c|}{$\begin{array}{c}\text { One-year } \\
\text { earnings (\%) }\end{array}$} & \multicolumn{2}{|c|}{$\begin{array}{l}\text { Five-year } \\
\text { average real } \\
\text { earnings (\%) }\end{array}$} \\
\hline & & 1995 & 2013 & 1995 & 2013 & 1995 & 2013 & 1995 & 2013 & 1995 & 2013 & 1995 & 2013 \\
\hline 1 & $\begin{array}{l}\text { Aggregate } \\
\text { dividends/ aggregate } \\
\text { earnings (payers and } \\
\text { non-payers pooled) }\end{array}$ & 25.77 & 31.59 & 44.57 & 77.47 & 27.14 & 39.13 & 51.28 & 105.22 & 25.51 & 29.39 & 43.44 & 70.28 \\
\hline
\end{tabular}




\section{Macrothink}

\begin{tabular}{|c|c|c|c|c|c|c|c|c|c|c|c|c|c|}
\hline 2 & $\begin{array}{l}\text { Aggregate dividends } \\
/ \text { total earnings of } \\
\text { dividend payers }\end{array}$ & 26.67 & 28.41 & 44.85 & 76.54 & 30.19 & 31.93 & 52.64 & 103.78 & 26.06 & 27.25 & 43.58 & 69.47 \\
\hline 3 & $\begin{array}{l}\text { Median firm's } \\
\text { payout ratio } \\
\text { (dividend payers) }\end{array}$ & 25.37 & 21.79 & 45.19 & 57.48 & 25.49 & 21.56 & 55.61 & 55.16 & 25.33 & 21.93 & 41.98 & 58.18 \\
\hline 4 & $\begin{array}{l}\text { Constant } \\
\text { composition sample } \\
\text { of firms that paid } \\
\text { dividends in both } \\
1995 \text { and } 2013 \text { : } \\
\text { total dividends/ total } \\
\text { earnings of these } \\
\text { dividend payers }\end{array}$ & 26.82 & 30.62 & 57.06 & 81.82 & 31.71 & 35.16 & 67.85 & 111.10 & 26.02 & 29.09 & 55.31 & 73.88 \\
\hline 5 & $\begin{array}{l}\text { Constant } \\
\text { composition sample } \\
\text { of firms that paid } \\
\text { dividends in both } \\
1995 \text { and 2013: } \\
\text { median firm's payout } \\
\text { ratio }\end{array}$ & 25.21 & 20.75 & 53.99 & 57.90 & 26.11 & 20.29 & 63.41 & 55.62 & 25.10 & 20.92 & 51.50 & 58.30 \\
\hline
\end{tabular}

Note: Row 1 measures the aggregate dividends payout ratio by dividing aggregate dividends by aggregate earnings of both payers and non-payers. While row 2 obtains payout ratio by dividing aggregate dividends by total earnings of dividend payers only. Row 3 depicts the median firm's payout ratio of dividend paying firms. Row 4 and 5 reports the aggregate and median firm's payout ratio for 442 firms that paid dividend in both years 1995 and 2013. Row 4 measure the dividend payout ratio as total dividend paid divided by total earnings of dividend payers for 442 constant composition sample firms. Row 5 reports the median firm's payout ratio of dividend paying firms within 442 firms. The column marked "one year earnings" measures the dividend payout ratio by considering one year's earnings during that year. While the column marked "five-year average real earnings" measures the payout ratio by considering the average of five year's earnings. For example, for a given firm in 2013 the earning is calculated as average of earnings over the five years 2009-2013, with each year's earnings converted to 2013 ₹ by using the GDP deflator.

\section{Summary and Conclusions}

This is the first study to investigate the behavior of aggregate dividends and earnings and the 
concentration of dividends and earnings in an emerging capital markets such as India, although this issue is examined in developed capital markets such as U.S., U.K. and Japan.

The numbers of dividend paying firms decreased from 620 in 1995 to 504 in 2013 whereas the aggregate nominal as well as real dividends increased by manifold over the last two decades. Although the aggregate nominal and real dividends increased by manifold over the last two decades neither the magnitude nor the trend of increase is comparable with the U.S. experience. This pattern reveals that there is concentration of dividends among dividend paying firms, with fewer firms paying most dividends.

The top 100 highest dividend paying firms supplied 73.29 per cent of aggregate dividends during 1995 and 89 per cent during 2013. We examined the earning pattern of these top 100 highest dividends paying firms and found that the earnings of top highest dividend paying firms represent 66.89 per cent of aggregate earnings in 1995 and 81.47 per cent in 2013 . While the earnings of lowest dividend paying firms represents very less proportion of aggregate earnings in 1995 and in 2013. Thus, there is concentration in earnings also, and this earnings concentration increased considerably over the last two decades.

The concentration in dividends and earnings is also observed among the standalone and business group affiliated firms, where the occurrence of concentration of dividends and earnings is more severe for business groups affiliated firms as compared to standalone firms. The business group affiliated firms creates internal capital markets for group members and are less dependent on external capital markets for funds acquisition. But the dividend policy of business group affiliated firms is more sensitive to informational asymmetry problem, which causes them to pay more dividends to reduce this informational asymmetry problem (Manos et al., 2012).

Consistent with the findings of DeAngelo et al. (2004) in U.S. context, there is emergence of two groups based on earnings in Indian capital market. The first group contains few firms with very high earnings and supplied major proportion of aggregate dividends. The second group consists of many firms with very low earnings and these firms contributed very little to the aggregate dividends supply. Certainly, the top nine dividend paying firms accounted for nearly 45 per cent of total aggregate dividend supply in the year 2013.

We also examine the cross-sectional distribution of earnings of firms to analyze the relationship between the dividends and earnings in details. The cross-sectional examination of earnings reveals that there is strong positive relationship between earnings and decision to pay dividends and an inverse relationship exists between losses and dividend payment decisions. Thus, the firms with high level of earnings are more likely to pay dividends while the firms suffering from losses are most likely to cut or omit the dividends.

We also investigate the firm's capacity to distribute its earnings in the form of dividends by constructing five different payout proxies. We find that the dividend payout ratio didn't decline for all sample Indian firms as well as for standalone and business group affiliated firms, but it increased slightly over the last two decades. Thus, there hasn't been reduced 
propensity to pay unlike the declining propensity to pay in global trends.

We conclude that there are dividends and earnings concentration among sample Indian firms and various forms of corporate organizational structure and this concentration increased considerably over the last two decades with fewer firms paying most dividends and emergence of two groups based on earnings and we do not find any evidence for reduced propensity to pay in Indian capital market.

\section{Acknowledgement}

I would like to thank Professor Anand Teltumbde, Vinod Gupta School of Management, Indian Institute of Technology Kharagpur, for his helpful comments and suggestions.

\section{References}

Aharony, J., \& Swary, I. (1980). Quarterly dividend and earnings announcements and stockholders' returns: An empirical analysis. The Journal of Finance, 35(1), 1-12. http://dx.doi.org/10.1111/j.1540-6261.1980.tb03466.x

Beim, D. O., \& Calomiris, C. W. (2001). Emerging financial markets. New York: McGraw-Hill Irwin.

Bhattacharya, S. (1979). Imperfect information, dividend policy, and "the bird in the hand" fallacy. The Bell Journal of Economics, 10(1), 259-270. http://dx.doi.org/10.2307/3003330

Black, F. (1976). The dividend puzzle. The Journal of Portfolio Management, 2(2), 5-8. http://dx.doi.org/10.3905/jpm.1976.408558

Black, F., \& Scholes, M. (1974). The effects of dividend yield and dividend policy on common stock prices and returns. Journal of financial economics, 1(1), 1-22. http://dx.doi.org/10.1016/0304-405X(74)90006-3

DeAngelo, H., DeAngelo, L., \& Skinner, D. J. (2004). Are dividends disappearing? Dividend concentration and the consolidation of earnings. Journal of Financial Economics, 72(3), 425-456. http://dx.doi.org/10.1016/S0304-405X(03)00186-7

DeAngelo, H., DeAngelo, L., \& Stulz, R. M. (2006). Dividend policy and the earned/contributed capital mix: a test of the life-cycle theory. Journal of Financial economics, 81(2), 227-254. http://dx.doi.org/10.1016/j.jfineco.2005.07.005

Denis, D. J., \& Osobov, I. (2008). Why do firms pay dividends? International evidence on the determinants of dividend policy. Journal of Financial Economics, 89(1), 62-82. http://dx.doi.org/10.1016/j.jfineco.2007.06.006

Easterbrook, F. H. (1984). Two agency-cost explanations of dividends. The American Economic Review, 650-659.

Fama, E. F., \& Babiak, H. (1968). Dividend policy: An empirical analysis. Journal of the American Statistical Association, $\quad$ 63(324), 1132-1161. 
http://dx.doi.org/10.1080/01621459.1968.10480917

Fama, E. F., \& French, K. R. (2001). Disappearing dividends: changing firm characteristics or lower propensity to pay? Journal of Financial economics, 60(1), 3-43. http://dx.doi.org/10.1016/S0304-405X(01)00038-1

Fatemi, A., \& Bildik, R. (2012). Yes, dividends are disappearing: Worldwide evidence. $\begin{array}{llll}\text { Journal of Banking \& } \quad \text { Finance, } & 36(3),\end{array}$ http://dx.doi.org/10.1016/j.jbankfin.2011.10.008

Ferris, S. P., Sen, N., \& Yui, H. P. (2006). Are fewer firms paying more dividends?: The international evidence. Journal of Multinational Financial Management, 16(4), 333-362. http://dx.doi.org/10.1016/j.mulfin.2005.08.002

Jensen, M. C., \& Meckling, W. H. (1976). Theory of the Firm: Managerial Behavior, Agency Costs and Ownership Structure. Journal of Financial Economics, 3(4), 305-360. http://dx.doi.org/10.1016/0304-405X(76)90026-X

Khanna, T., \& Rivkin, J. W. (2001). Estimating the performance effects of business groups in emerging markets. Strategic management journal, 22(1), 45-74. http://dx.doi.org/10.1002/1097-0266(200101)22:1<45::AID-SMJ147>3.0.CO;2-F

La Porta, R., Lopez - de - Silanes, F., Shleifer, A., \& Vishny, R. W. (2000). Agency problems and dividend policies around the world. The Journal of Finance, 55(1), 1-33. http://dx.doi.org/10.1111/0022-1082.00199

Lintner, J. (1956). Distribution of incomes of corporations among dividends, retained earnings, and taxes. The American Economic Review, 46(2), 97-113.

Litzenberger, R. H., \& Ramaswamy, K. (1979). The effect of personal taxes and dividends on capital asset prices: Theory and empirical evidence. Journal of financial economics, $7(2)$, 163-195. http://dx.doi.org/10.1016/0304-405X(79)90012-6

Lukose, J., \& Komera, S. (2013, December). Disappearing dividends and patterns in payout policy: Evidence on the determinants of dividend policy in India. Paper presented at India Finance Conference, IIM - Ahmedabad, India.

Manos, R., Murinde, V., \& Green, C. J. (2012). Dividend policy and business groups: Evidence from Indian firms. International Review of Economics \& Finance, 21(1), 42-56. http://dx.doi.org/10.1016/j.iref.2011.05.002

Miller, M. H. (1977). Debt and Taxes. The Journal of Finance, 32(2), 261-275.

Miller, M. H., \& Modigliani, F. (1961). Dividend policy, growth, and the valuation of shares. The Journal of Business, 34(4), 411-433. http://dx.doi.org/10.1086/294442

Reddy, Y. S., \& Rath, S. (2005). Disappearing Dividends in Emerging Markets?: Evidence from India. Emerging Markets Finance and Trade, 41(6), 58-82. 


\section{Macrothink}

Business Management and Strategy

ISSN 2157-6068

2016, Vol. 7, No. 1

Rozeff, M. S. (1982). Growth, beta and agency costs as determinants of dividend payout

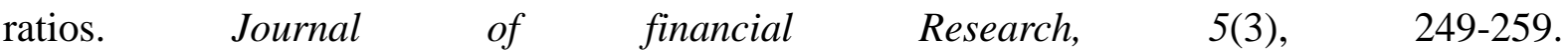
http://dx.doi.org/10.1111/j.1475-6803.1982.tb00299.x

Singhania, M. (2005). Trends in dividend payout: a study of select Indian companies. Journal of Management Research, 5(3), 129-142.

von Eije, H., \& Megginson, W. L. (2008). Dividends and share repurchases in the European $\begin{array}{lllll}\text { Union. Journal of Financial } & \text { Economics, } & \text { 89(2), }\end{array}$ http://dx.doi.org/10.1016/j.jfineco.2007.11.002

\section{Copyright Disclaimer}

Copyright for this article is retained by the author(s), with first publication rights granted to the journal.

This is an open-access article distributed under the terms and conditions of the Creative Commons Attribution license (http://creativecommons.org/licenses/by/3.0/). 